The Implied Risk Premium and Firm Risk Characteristics

\author{
Pengguo Wang ${ }^{1}$ \\ Xfi Centre for Finance and Investment \\ Exeter University Business School \\ Exeter EX4 4ST, UK \\ p.wang@exeter.ac.uk
}

\footnotetext{
${ }^{1}$ I thank David Ashton, Mark Clatworthy, Richard Harris, Alan Gregory, Peter Pope and seminar participants at University of Exeter for helpful comments and suggestions. I am grateful to Inquire-UK for funding support of this project. This article represents the views of the author and not of Inquire UK.
} 


\title{
The Implied Risk Premium and Firm Risk Characteristics
}

\begin{abstract}
This paper proposes a new approach to infer a firm-specific measure of the implied cost of capital. It incorporates endogenously estimated industry-year growth rate of the net present value of future investments. It requires only one-year-ahead forecasts of earnings, and dividend payout policy is irrelevant. The measure is intrinsically linked to commonly used accounting ratios including book-to-market, (forward) earnings yield, dividend-to-price as well as growth and past returns. It is significantly positively associated with future realized stock returns and also significantly correlates with commonly used risk characteristics in a theoretically predicted manner.
\end{abstract}

Keywords: Expected returns, Implied risk premium, Growth, Earnings forecasts, Asset pricing test

JEL: G12, G14, G29, G31, G32, M40, M41 


\section{The Implied Risk Premium and Firm Risk Characteristics}

\section{Introduction}

In this paper, I propose a new approach to estimate firm-specific implied cost of equity capital (ICC). It incorporates endogenously estimated industry-year long-term growth rates of the net present value (NPV) in future investments and intrinsically links to well-established accounting ratios, such as book-to-market, dividend-to-price and (forward) earnings yields. It has the ability to explain future realized stock returns and significantly correlates with commonly used risk characteristics, such as the CAPM beta, size, leverage and default spread, in a theoretically predicted manner.

The ICC is the internal rate of return or the discount rate under which the market price of equity is equal to the present value of all expected future cash flows when one assumes a flat term structure. Alternatively, it is the capitalization rate under which the market price of equity is equal to a linear combination of capitalized (current available) financial information variables and future growth information. ${ }^{2}$ A growing number of studies in finance and accounting employ the ICC as a proxy of expected stock returns. ${ }^{3}$ Pastor, Sinha and Swaminathan (2008) show theoretically that under plausible conditions the ICC can be perfectly correlated with the conditional expected stock return. The collective evidence shows that the ICC approach may help us understand several puzzles in empirical asset pricing. ${ }^{4}$

\footnotetext{
${ }^{2}$ This notion allows a non flat term structure of the implied cost of capital. The ICC in this paper is consistent with this notion.

${ }^{3}$ The representative methods apply the residual income models (Claus and Thomas (2001), Gebhardt, Lee and Swaminathan (2001), Easton, Taylor, Shroff and Sougiannis (2002), Nekrasov and Ogneva (2011), Hou, van Dijk and Zhang (2012)), the Ohlson and Juettner-Nauroth (2005) model (Gode and Mohanram (2003), Easton (2004)), the Feltham and Ohlson (1996) model (Ashton and Wang (2012)), or the Gordon growth model (Gordon and Gordon (1997)).

${ }^{4}$ Easton (2009) provides a summary of the literature on the ICC in accounting. Pastor, et al. (2008) apply the ICC approach to test the Intertemporal CAPM, while Lee, $\mathrm{Ng}$, and Swaminathan (2009) use the ICC to test international asset pricing models. The ICC methodology has been used to examine whether cross-listing
} 
Despite their appealing features, existing implied cost of capital models have methodological limitations. First, the terminal growth rate used to truncate infinite future cash flows in a valuation model is often assumed by researchers. For example, Claus and Thomas (2001) assume that residual incomes grow at the same rate (i.e. an estimate of the expected inflation rate) across all firms. ${ }^{5}$ Second, dividend payout policy is usually supposed over a forecast period, and multiperiod forecasts of earnings are normally required. For instance, Easton, et al. (2002) require up to four years of earnings forecasts and assume that the expected dividends in the subsequent four years are equal to the current dividends paid. ${ }^{6}$ These limitations consequently result in a large range of estimates of the implied equity risk premium. ${ }^{7}$ It is not surprising that the correlations between most expected return proxies and realized returns are not statistically different from zero, and the cross-sectional relation between the various ICC measures and firm-specific risk characteristics is inconclusive (Botosan and Plumlee (2005), Easton and Monahan (2005)). ${ }^{8}$

Most recently, Ashton and Wang (2012 AW) develop an approach to estimate simultaneously the capitalization rate (the ICC) and growth rate of the NPV of future investments under some weaker assumptions. Their method does not explicitly assume

reduces foreign firms' cost of capital and the effectiveness of a country's legal institutions and securities regulation (Hail and Leuz (2006, 2009)). The ICC approach has also been employed to investigate default risk (Chava and Purnanadam (2009)) and executive pay disparity (Chen, Huang and Wei (2012)). These studies provide evidence on relation between risk and return that is more consistent with theoretical predictions than those obtained using ex post realized stock returns.

${ }^{5}$ Gebhardt et al. (2001) assumes a convergence in profitability to an industry average over 12 years with a zero terminal growth thereafter. Gode and Mohanram (2003) assume that a firm's growth in residual income reverts to an economy-wide level.

${ }^{6}$ Gebhardt et al. (2001) assume that firms have a 100\% dividend payout ratio beyond the forecast horizon. Claus and Thomas (2001) assume that 50\% of earnings are retained each period. Easton (2004) supposes that next period dividend equals current fiscal year end dividend. Nekrasov and Ogneva (2011) require up to four years of earnings forecasts and assume that the expected dividends in the subsequent four years are equal to current dividends paid. In addition, they require a long-run growth rate from the I/B/E/S.

${ }^{7}$ Based on a US sample over 1970-2007, Lee, So and Wang (2011) find that the median equity risk premium is $1.8 \%$ when applying the residual income model and $8.42 \%$ when applying the Ohlson and Juettner-Nauroth model.

${ }^{8}$ Some studies find a positive relation between the ICC and market beta (Kaplan and Ruback (1995), Gode and Mohanram (2003)), and some find a negative relation (Easton and Monahan (2005), Hou et al. (2012) ), while others find this relation to be mostly insignificant (Gebhardt et al. (2001), Lee et al. (2009), Nekrasov and Ogneva (2011)). 
dividend payout policy and requires only one-year-ahead forecasts of earnings. However, it only allows one to estimate the average ICC and average growth rate for a given portfolio of firms. This paper extends the AW approach to allow for a firm-specific measure of the ICC. It is shown that the firm-specific measure of the ICC is intrinsically linked to the commonly used firm-specific accounting ratios including book-to-market, (forward) earnings yield, dividend-to-price, as well as growth and past returns in an analytic form. The multiples on these accounting ratios and growth of the NPV of future investments can be estimated according to a long-standing industry practice of using a benchmark industry averages in the valuation of a firm (Damodaran (2002), Liu, Nissim and Thomas (2002), Walker and Wang (2003), Pratt and Niculita (2007), Penman (2010)). ${ }^{9}$ This is also consistent with Fama and French (1997) findings in which there are substantial variations in factor loadings across industries.

The analytic expression of the ICC has a number of desirable properties which show the relationship between expected return and risk proxies. Firstly, it yields the insight that expected returns are associated with the risk that is related to uncertainty about the growth of future positive NPV investments. Beaver, Kettler and Scholes (1970) assert that abnormal earnings arising from growth opportunities are inherently more risky, leading to a positive association between expected return and growth. Characteristics that are associated with risky future growth are identified as explaining the expected return. ${ }^{10}$ This provides an explanation for why book-to-price $(\mathrm{B} / \mathrm{P})$ may be useful for explaining expected stock returns. $\mathrm{B} / \mathrm{P}$ interacts with the growth of future investments, so investors may rationally take into account in pricing equity shares. The expression of the ICC clearly shows that P/B itself does not

\footnotetext{
${ }^{9}$ It implicitly assumes that market multiples are the same for each firm in the same industry in a year.

${ }^{10}$ Liew and Vassalou (2000) find that book-to-market and size portfolios are related to future growth in the real economy. Book-to-price has been explained as growth options (Berk, Green and Naik (1999)) and investment and asset growth (Cooper, Gulen and Schill (2008)). Vassalou (2003) argues that news related to future GDP growth can explain the cross-section of equity returns as well as the Fama-French model can.
} 
represent growth as commonly viewed, but B/P amplifies the growth of the NPV of future investments. In contrast to what is documented in Fama and French (1992) and others, B/P should be negatively related to expected returns if one controls for (forward) earnings yield, and dividend-to-price for firms with expected positive growth. If there is no growth, then $\mathrm{B} / \mathrm{P}$ should not have explanatory power to expected returns after controlling for the firm's other characteristics. In other words, $\mathrm{B} / \mathrm{P}$ adds to expected returns only if it amplifies growth that is associated with differential risk in the cross-section. In this sense, it is the expected growth that is a priced risk factor. Growth is risky, and one cannot have more risky investments without taking on more risk. ${ }^{11}$

Secondly, it shows that expected returns are associated with the risk that is related to uncertainty about future earnings. Forward earnings yield is identified as an omitted factor in the standard asset pricing models and the Fama and French factor model. ${ }^{12}$ Earnings-to-price and dividend-to-price have been widely used as predictors of equity risk premia, for example Ball (1978), Fama and French (1988, 1992, 1993), Campbell and Shiller (1988, 1998) and Campbell and Thompson (2008). The forward earnings-to-price has long been used in equity valuation by financial analysts. However, it appears that not enough attention has been paid to forward earnings in the empirical asset pricing literature (Fame and French (2006)). When earnings fail to meet analysts' forecasts - a proxy of market expectations of future earnings, stock prices are shocked.

Thirdly, it provides an alternative explanation as to what contributes to the momentum premium. The stock return persistence for the intermediate horizon (6 to 12 months) is well-established across markets and industries, among asset classes and over time (for example, Rouwenhorst (1998), Chan, Hameed and Tong (2000), Okunev and White

\footnotetext{
${ }^{11}$ Recent studies (e.g. Penman, Reggiani, Richardson and Tuna (2011), Penman and Reggiani (2012)) make a similar argument, albeit from different perspectives.

${ }^{12}$ Penman et al. (2011) also identify forward earnings yield as an omitted risk factor from a characteristic model.
} 
(2003), Jegadeesh and Titman $(1993,2001))$. The analytic expression of the ICC implies that momentum is a combined effect of both common component and firm-specific characteristics. Current returns relate to future returns due to accounting conservatism. Accounting conservatism understates 'true' incomes, or only recognizes a portion of economic earnings. Unrecognized portion will be recognized in a later stage and may be reflected in future returns. ${ }^{13}$ Conservative accounting principles apply to all firms in a capital market. However, different firms may apply different accounting policies under common principles. The conservative nature of reporting may influence investors' beliefs about future profitability when expectations of growth and future earnings are formed.

Prior literature that assesses the validity or reliability of firm-specific estimates of the ICC has been focused on the explanatory power for future realized returns and on correlations with commonly used risk proxies. As indicated by the ICC expression that firm characteristics including growth of future investments, earnings-to-price, dividend-to-price and past returns are the main ingredients in the calculation of the dependent variable (the estimate of expected rate of return), care must be taken when explaining the ICC by using these risk proxies. Otherwise a spurious effect is inevitable. Botosan and Plumlee (2005) and Easton (2009) argue that such spurious effects are likely for most (perhaps all) ICC estimates. Clearly the analytic form of the ICC makes my testing more objective. In light of these spurious influences, the CAPM beta, size, leverage, term spread and default spread are my main interest risk proxies.

I show that my proxy of expected return is significantly positively associated with future realized stock returns for a sample of I/B/E/S firms over the period 1980-2010. The measure remains significantly positively related to future realized stock returns, even after

\footnotetext{
${ }^{13}$ If an asset is over depreciated, for instance, then it will be under depreciated at some future date as there exists a reversing process.
} 
controlling for commonly used risk proxies (the CAPM beta, size and leverage) and cash flow news and discount rate news (Campbell (1991), Vuolteenaho (2002)), as well as term spread and default spread (Fama and French (1989)). I also document the ICC's out-ofsample predictive ability with respect to future stock returns by sorting firms into quintiles of ICC distribution each year. For each portfolio, I calculate the mean buy-and-hold return for the next 12 months. I find that my measure ICC exhibits a monotonic relation with future realized returns. The measure is also associated with conventional risk characteristics in a theoretically predictable manner. Specifically, I find a significant positive relation between expected risk premium and market beta, leverage, cash flow news, default spread and negative association between implied risk premium and firm size. When I adjust the $\mathrm{I} / \mathrm{B} / \mathrm{E} / \mathrm{S}$ consensus forecasts for predictable errors (Hughes, Liu and Su (2008)), I find that these relations are strengthened.

This paper makes a number of contributions to the literature. First, it introduces a conceptually-sound, computationally-simple methodology to derive firm-specific risk premium estimates. Second, it explores an analytic expression of a proxy of expected stock return and identifies missing explanatory factors, such as the growth of the NPV of future investments and forward earnings yield, in prior empirical asset pricing literature. Third, it offers an interpretation as to why book-to-price and past returns may be useful for explaining expected returns. Finally, it introduces a new cross-sectional model to adjust the I/B/E/S consensus forecasts of earnings for predictable errors. ${ }^{14}$

The rest of the paper is organized as follows. Section 2 summarizes the AW model and discusses the intrinsic relationship between the implied cost of equity capital and various accounting risk characteristics. Section 3 describes my sample and empirical implementation.

\footnotetext{
${ }^{14}$ The cross-sectional model itself can be used to forecast the earnings of individual firms.
} 
Section 4 provides the estimation results and assesses the validity of my estimates. Section 5 concludes.

\section{Implied Cost of Capital and Risk Factors}

Estimating the implied cost of capital necessarily relies on a valuation model. The model employed in this paper is built on Feltham and Ohlson (1996) and Ashton and Wang (2012). Feltham and Ohlson (1996) develop their valuation model based on the following three economic and accounting assumptions. First, equity value is equal to the present value of all future expected dividends, namely the no-arbitrage condition. Second, dividends are equal to earnings subtracting the changes in book values, or the clean surplus accounting identity. Third, a system that describes cash receipts and cash investments follows a (vector) autoregressive process. With these assumptions, equity value is then expressed as a linear combination of (lagged) book value, abnormal earnings and a value-added term. ${ }^{15}$ This valueadded component is shown to be equal to the NPV from a marginal dollar project multiplied by the current cash investment level. Consequently, it is proportional to the growth of the future investment. Instead of describing the cash inflow dynamics in Feltham and Ohlson (1996), however, AW directly assume that equity value can be written in terms of contemporary book value, earnings, dividends and an 'other economical information' term that captures the present value of all future investment projects. Consistent with Feltham and Ohlson (1996), AW assume that the present value of future growth opportunity (PVGO) has a constant growth.

\subsection{A Model of Forecasting of Earnings}

${ }^{15}$ See Proposition 2 (page 216) in Feltham and Ohlson (1996). 
I summarize the AW model as below. Firstly, consistent with Miller and Modigliani (1961), it is an investment policy that determines the value of equity, and dividends displace both book value and market value dollar-for-dollar. Cum-dividend equity value is expressed in terms of cum-dividend book value $\left(b_{t}\right)$, earnings $\left(e_{t}\right)$ and the net present value of all future investments $\left(\vartheta_{t}\right)$, i.e.

$$
P_{t}=\alpha_{1}\left(b_{t}+d_{t}\right)+\alpha_{2} e_{t}-d_{t}+\vartheta_{t}
$$

where dividends $\left(d_{t}\right)$ and prices $\left(P_{t}\right)$ satisfies the no-arbitrage condition: $E_{t}\left[P_{t+1}+d_{t+1}\right]=R P_{t}$, $R$ is one plus the cost of equity capital, and $E_{t}[]$ represents expectation based on available information at time t. Valuation multiples $\alpha_{1}$ and $\alpha_{2}$ in equation (1) are positive since equity value is expected to increase in the firm's book value and earnings in general. In fact, one can expect $\alpha_{1} \geq 1$ for a majority of firms since book values are understated under conservative accounting. $^{16}$

Secondly, the net present value of future ex ante investments is assumed to grow on average at a rate of $g$ :

$$
\vartheta_{t+1}=(1+g) \vartheta_{t}+\lambda\left(P_{t}-P_{t-1}+d_{t}-e_{t}\right)+\varepsilon_{t+1}
$$

where $\varepsilon_{t+1}$ is an error term with mean zero and $1+\mathrm{g}<\mathrm{R}$. The second term on the right hand side of equation (2) adjusts for the potential impact of accounting conservatism since conservatism in reporting may influence beliefs about future profitability when the expectation of growth is formed. ${ }^{17}$ Here conservatism is measured by the difference between economic earnings, $\left(P_{t}-P_{t-1}+d_{t}\right)$, and accounting earnings. Under conservative accounting,

\footnotetext{
${ }^{16}$ For example, physical assets are recorded at historical costs; inflation and associated asset holding gains are ignored; R\&D is sometimes viewed as an expense rather than an investment; and many intangible assets are not recognized.

${ }^{17}$ Claus and Thomas (2001) and Easton (2009) argue that expected growth is affected by both the expectation of future economic rents and the conservative nature of accounting.
} 
the parameter $\lambda$ is expected to be positive so that growth rate, $g$, is less than it would be when economic earnings are equal to accounting earnings. ${ }^{18}$

Equations (1) and (2), together with the no-arbitrage condition and clean surplus accounting (i.e., $\left.b_{t}+d_{t}=e_{t}+b_{t-1}\right)$, imply that expected one-year-ahead earnings can be written as

$$
\begin{aligned}
E_{t}\left[e_{t+1}\right] & =\frac{R-(1+g)-\lambda}{\left(\alpha_{1}+\alpha_{2}\right)} P_{t}+\frac{(1+g)\left(\alpha_{1}+\alpha_{2}-1\right)}{\left(\alpha_{1}+\alpha_{2}\right)} e_{t}+\frac{\left(1+g-\alpha_{1}+\lambda\right)}{\left(\alpha_{1}+\alpha_{2}\right)} b_{t} \\
& +\frac{(1+g)\left(\alpha_{1}-1\right)-\lambda}{\left(\alpha_{1}+\alpha_{2}\right)} b_{t-1}+\frac{\lambda}{\left(\alpha_{1}+\alpha_{2}\right)} P_{t-1} .
\end{aligned}
$$

The above can be viewed as a forecasting model of earnings. It is a formalization of the arguments of Richardson, Tuna and Wysocki (2010). Specifically, prices $\left(P_{t}\right)$ or returns $\left(\Delta P_{t}\right)$ are leading indicators of future earnings, and earnings $\left(e_{t}\right)$ are persistent. In addition, future earnings are generated from the current equity and affected by changes in book values of equity ( $\Delta b_{t}$ or accounting accruals). From equation (3), I expect that $\alpha_{1}+\alpha_{2}$ is greater than 1 if future earnings are positively related to current earnings as evidenced in prior literature (Fama and French (2006), Hou and Robinson (2006)). I also expect $R>1+g+\lambda$ if price leads earnings as documented in the existing literature (for example, Weiss, Naik and Tsai $(2005)){ }^{19}$

\subsection{Implied Cost of Capital and Risk Characteristics}

Applying the clean surplus relation, the implied cost of equity capital in equation (3) can be expressed in terms of growth, expected changes in forward earnings yield, retained earnings to price and dividend-to-price, as well as the past return as below:

\footnotetext{
${ }^{18}$ Prior studies assume either abnormal earnings growth (Gebhart et al. (2001), Claus and Thomas (2001), Easton et al. (2002), Nekrasov and Ogneva (2011)) or abnormal growth in earnings (Gode and Mohanram (2003), Easton (2004), Ohlson and Juettner-Nauroth (2005)) or dividend growth (Gordon and Gordon (1997), Botosan and Plumlee (2005), Botosan et al. (2012)). These are in contrast with the growth rate in Ashton and Wang (2012).

${ }^{19}$ This would imply that the conservatism parameter is a relatively small number, $\lambda<R-(1+g)$.
} 


$$
R-1=g \frac{\vartheta_{t}}{P_{t}}+\left(\alpha_{1}+\alpha_{2}\right) \frac{\Delta E_{t}\left[e_{t+1}\right]}{P_{t}}+\left(\alpha_{1}-\lambda\right) \frac{e_{t}-d_{t}}{P_{t}}+(1-\lambda) \frac{d_{t}}{P_{t}}+\lambda \frac{\left(P_{t}+d_{t}-P_{t-1}\right)}{P_{t}}
$$

where $\Delta E_{t}\left[e_{t+1}\right]=E_{t}\left[e_{t+1}\right]-e_{t}$. Equivalently, the ICC can be expressed in terms of fundamental accounting ratios and past returns. Therefore five factors: growth of the NPV of future investments, dividend-to-price, both earnings yield and forward earnings yield, and past returns can be used to explain a firm's expected return.

To link the findings in the existing literature, it is useful to elaborate the properties of this proxy of expected stock return formula. Notably, growth is risky and should be priced. The expected growth rate not only summarizes future macroeconomic prospect but also reflects firm-specific characteristics. While the business environment is a common factor across firms, firm-specific characteristics including book-to-price $(\mathrm{B} / \mathrm{P})$, earnings-to-price (E/P) and dividend-to-price (D/P) may interact with growth, and hence affect the expected return.

It is interesting to note that the commonly used 'risk factor' $\mathrm{B} / \mathrm{P}$ has no explanatory power to expected return after controlling for growth and other ratios. ${ }^{20}$ However, $\mathrm{B} / \mathrm{P}$ is associated with growth since $\frac{\vartheta_{t}}{P_{t}}$ in equation (4) can be written as $\frac{\vartheta_{t}}{P_{t}}=1-\alpha_{1} \frac{b_{t}}{P_{t}}-\alpha_{2} \frac{e_{t}}{P_{t}}-\left(\alpha_{1}-1\right) \frac{d_{t}}{P_{t}} \cdot{ }^{21}$ Price-to-book itself may not represent growth as commonly interpreted, but it amplifies the growth. Ohlson (2005) addresses this issue based on the residual income valuation model. When one truncates abnormal earnings at time $t+1$, and assumes a growth rate ( $g$ ) for abnormal earnings, or equivalently in my case: $\alpha_{1}=1, \alpha_{2}=0, \lambda=0$, equation (4) reduces to

\footnotetext{
${ }^{20}$ Note that retained earnings $e_{t}-d_{t}$ is equal to the changes in book value $\Delta b_{t}=b_{t}-b_{t-1}$ under clean surplus accounting.

${ }^{21}$ Penman et al. (2011) find that "there is a surprise: $\mathrm{b} / \mathrm{p}$, rather than $\mathrm{p} / \mathrm{b}$ forecasts growth, calling into question the standard dichotomy of "value' vs 'growth".
} 


$$
R-1=g+\frac{E_{t}\left[e_{t+1}\right]}{P_{t}}-g \frac{b_{t}}{P_{t}}
$$

This leads Ohlson (2005) to argue that $\mathrm{B} / \mathrm{P}$ should be negatively related to expected return after controlling for growth and forward earnings yield. This is in contrast to a large body of empirical asset pricing literature. In equation (5), when a firm has no growth $(g=0)$, then the expected rate of return is equal to the expected earnings yield. The positive association between $\mathrm{B} / \mathrm{P}$ and expected returns becomes apparent when we control for forward earnings yield and ratio of one-period-ahead NPV of future investments to price, and rewrite equation (4) as the following equation: ${ }^{22}$

$$
R=\frac{E_{t}\left[\vartheta_{t+1}\right]}{P_{t}}+\alpha_{1} \frac{b_{t}}{P_{t}}+\left(\alpha_{1}+\alpha_{2}\right) \frac{E_{t}\left[e_{t+1}\right]}{P_{t}}
$$

When regressing expected return on book-to-price, and either reasonable proxies for $\frac{E_{t}\left[\vartheta_{t+1}\right]}{P_{t}}$ and $\frac{E_{t}\left[e_{t+1}\right]}{P_{t}}$, or both forward ratios are missing, one would observe that $\mathrm{B} / \mathrm{P}$ is positively related to expected returns. This is consistent with findings in Fama and French (1988, 1992, 1993) and others.

Finally, past returns may be useful in explaining expected returns (momentum) due to accounting conservatism. ${ }^{23}$ When accounting is unbiased $(\lambda=0)$, the past return term disappears in equation (4). The proxy of expected returns becomes

$$
R-1=\frac{E_{t}\left[e_{t+1}\right]}{P_{t}}+g \frac{\vartheta_{t}}{P_{t}}+\left(\alpha_{1}+\alpha_{2}-1\right) \frac{\Delta E_{t}\left[e_{t+1}\right]}{P_{t}}+\left(\alpha_{1}-1\right) \frac{\Delta b_{t}}{P_{t}}
$$

\footnotetext{
${ }^{22}$ In Feltham and Ohlson (1996), $\alpha_{1}$ and $\alpha_{2}$ are negatively related to the discount rate $R$. Because both $\alpha_{1}$ and $\alpha_{2}$ are positive, the positive association between expected return and $\mathrm{B} / \mathrm{P}$ as well as forward $\mathrm{E} / \mathrm{P}$ will not be affected although it is in a nonlinear manner.

${ }^{23}$ Behavioral finance offers different explanation.
} 
The latter expression shows that the expected return is equal to expected forward earnings yield, adjusted by a long-run growth term $(\mathrm{g})$, a short-run earnings growth term $\left(\Delta E_{t}\left[e_{t+1}\right]\right)$ and investment in equity $\left(\Delta b_{t}=e_{t}-d_{t}\right)$.

In short, without properly controlling for growth and net present value of future investments, it is clear that book-to-market, dividend-to-price, both earnings yield and forward earnings yield, as well as past returns are intrinsically linked to the implied cost of capital.

\section{Describing Sample and Empirical Implementation}

\subsection{Sample Description}

My sample includes all NYSE, Amex and Nasdaq listed securities. Data are extracted from the CRSP monthly returns file from January 1975 to June 2011, and the Compustat industrial annual file from 1978 to 2010 and forecasts of earnings from the Institutional Brokers Estimate System (I/B/E/S) between 1979 and 2010. The adjusted number of shares outstanding and adjusted price at the end of the fiscal year, and adjusted price of equity three months after the fiscal year-end are collected from CRSP. ${ }^{24}$ I use stock price three months after the fiscal year-end to ensure that information about the prior year financials has been incorporated in the analysts' forecasts of earnings. Accordingly, I calculate 12-month buyand-hold returns for each firm from April to March each year. ${ }^{25}$ This is also consistent with the factor that a majority of firms have fiscal year end in December. ${ }^{26}$ Relevant accounting

\footnotetext{
${ }^{24}$ The cumulated adjustment factors for number of share and for stock price are collected from CRSP to calculate the adjusted number of shares outstanding and the adjusted price.

${ }^{25}$ This is in contrast with returns calculated from July to June in Fama and French $(1992,1993,1995)$ and others. Company financials become public information much more quickly compared with two decades ago due to technological advances. In addition, companies are now required by law to publish their accounts in 2-3 months after their fiscal year-end.

${ }^{26}$ The main results are not altered when I do my analysis for December fiscal year-end firms only.
} 
data are collected from Compustat. Firms with negative book values (CEQ) are deleted. Earnings are measured as net income before extraordinary items (IB). I use the median consensus forecasts of earnings per share at the first month after the corresponding I/B/E/Sreported prior-year earnings announcements. All total variables used in my estimation are divided by the adjusted number of shares outstanding to reduce heteroskedasticity and increase comparability across time. I measure size as the logarithm of a firm's market capitalization, leverage as the total debt divided by the firm's market capitalization as of 3months after the fiscal year end. Total debt is the sum of long-term debt (DLTT) and shortterm debt (DLC). Market beta is estimated via the market model using the value weighted NYSE/Amex market index return using at least 18 and up to 60 months of lagged monthly returns. The standard deviations of monthly returns are also computed using at least 18 months of data over the prior 60 months as a measure of total risk.

In constructing my data set, I delete $1 \%$ at the top and bottom of book value, earnings, stock price, number of shares outstanding, and analysts' consensus forecasts of earnings to avoid the influence of extreme observations.

\section{$<$ Insert Table 1 about here>}

Table 1, Panel A presents the descriptive statistics of the sample firms and analysts' consensus forecasts of earnings. We observe that the median of analysts' forecasts is about $28 \%$ higher than that of actual reported earnings. While the mean (median) book-to-price is about $0.84(0.56)$, the mean of earnings-to-price and the mean of one-year-ahead forward earningsto-price are $4.8 \%$ and $6.7 \%$ respectively.

Table 1, Panel B shows the annual cross-sectional correlations for 60,170 observations over the 31 year period from 1980 to 2010. The upper (lower) right triangle of the matrix presents Spearman (Pearson) correlations. These correlations show that 
contemporary price and current earnings are the variables most correlated with the forecasts of earnings.

\subsection{Empirical Implementation}

My analysis needs only one-year-ahead forecasts of earnings. Once the one-yearahead forecasts of earnings $\left(e_{t+1}\right)$ and other contemporary variables for a firm or portfolio of firms are known, I can run the following regression:

$$
e_{t+1}=\delta_{1} P_{t}+\delta_{2} e_{t}+\delta_{3} b_{t}+\delta_{4} b_{t-1}+\delta_{5} P_{t-1}+\varepsilon_{e, t+1}
$$

where $\varepsilon_{e, t+1}$ is an error term. The coefficients, $\delta_{1}-\delta_{5}$ and equation (3) then imply the following sample average growth rate $(g)$, cost of capital $(R)$, valuation multiples $\left(\alpha_{1}\right.$ and $\left.\alpha_{2}\right)$ and conservatism parameter $(\lambda)$ :

$$
\begin{gathered}
1+g=\frac{1+\delta_{2}+\delta_{3}-\delta_{5}+\sqrt{\left(1+\delta_{2}+\delta_{3}-\delta_{5}\right)^{2}-4\left(\delta_{2}-\delta_{4}-\delta_{5}\right)}}{2}, \\
R=(1+g)\left(1+\frac{\delta_{1}+\delta_{5}}{1+g-\delta_{2}}\right), \\
\alpha_{1}=1+\frac{\delta_{4}+\delta_{5}}{(1+g)-\delta_{2}}, \\
\alpha_{2}=\frac{\delta_{2}-\delta_{4}-\delta_{5}}{(1+g)-\delta_{2}}, \\
\lambda=\frac{(1+g) \delta_{5}}{1+g-\delta_{2}} .
\end{gathered}
$$

Consistent with industry practice, next I use sample average growth rate and valuation multiples as common factors for all firms in each industry-year portfolio to infer the ICC. Therefore a firm-specific expected rate of return, $\bar{r}_{t}=\bar{R}_{t}-1$, at time $t$ can be estimated by rewriting equation (4) as 


$$
\begin{aligned}
\bar{r}_{t} & =\left(1+\bar{g}_{i t}\right)\left[1-\frac{b_{t}}{P_{t}}-\left(\bar{\alpha}_{1, i t}-1\right) \frac{b_{t-1}}{P_{t}}-\left(\bar{\alpha}_{1, i t}+\bar{\alpha}_{2, i t}-1\right) \frac{e_{t}}{P_{t}}\right]+\bar{\alpha}_{1, i t} \frac{b_{t}}{P_{t}}+\left(\bar{\alpha}_{1, i t}+\bar{\alpha}_{2, i t}\right) \frac{E_{t}\left[e_{t+1}\right]}{P_{t}} \\
& +\bar{\lambda}_{i t}\left[\frac{P_{t}-b_{t}-\left(P_{t-1}-b_{t-1}\right)}{P_{t}}\right]-1,
\end{aligned}
$$

where $\bar{g}_{i t}, \bar{\alpha}_{1, i t}, \bar{\alpha}_{2, i t}$ and $\bar{\lambda}_{i, t}$ are average growth rate, valuation multiples and conservatism parameter respectively for firms in industry $i$ and year $t$. Here $\vartheta_{t}$ is replaced by using equation (1) and $d_{t}=e_{t}-\left(b_{t}-b_{t-1}\right)$. It can also be rewritten as

$$
\begin{aligned}
\bar{r}_{t} & =\bar{g}_{i t}+\left(1+\bar{g}_{i t}\right) \frac{d_{t}}{P_{t}}+\bar{\alpha}_{1, i t} \frac{b_{t}-\left(1+\bar{g}_{i t}\right) b_{t-1}}{P_{t}}+\left(\bar{\alpha}_{1, i t}+\bar{\alpha}_{2, i t}\right) \frac{E_{t}\left[e_{t+1}\right]-\left(1+\bar{g}_{i t}\right) e_{t}}{P_{t}} \\
& +\bar{\lambda}_{i t}\left[\frac{P_{t}-b_{t}-\left(P_{t-1}-b_{t-1}\right)}{P_{t}}\right] .
\end{aligned}
$$

It is clear that the dividend growth model is a special case. ${ }^{27}$

I subtract the 10-year US government bond yield from the ICC to compute the implied risk premium. This implied risk premium is the measure of the expected risk premium (ERP) that I use in the following regression tests.

To examine the incremental explanatory power of the ICC on future realized returns, I test the relation between one-year-ahead excess realized stock returns (i.e. one-year-ahead realized returns subtracted by the 10-year US government bond yield, XRET1) on the ERP and other control variables. These control variables include the unexpected return due to cash flow news, discount rate news and conventional risk characteristics: the CAPM beta, book-tomarket, firm size, leverage, term spread and default spread. A positive correlation between

\footnotetext{
${ }^{27}$ To see this, assume $\bar{\alpha}_{1, i t}=1, \bar{\alpha}_{2, i t}=0, E_{t}\left[b_{t+1}\right]=\left(1+\bar{g}_{i t}\right) b_{t}, \bar{\lambda}_{i t}=0$, and clean surplus accounting. We have $\bar{r}_{t}=\bar{g}_{i t}+\left(1+\bar{g}_{i t}\right) \frac{d_{t}}{P_{t}}+\frac{b_{t}-\left(1+\bar{g}_{i t}\right) b_{t-1}}{P_{t}}+\frac{E_{t}\left[e_{t+1}\right]-\left(1+\bar{g}_{i t}\right) e_{t}}{P_{t}}=\bar{g}_{i t}+\frac{E_{t}\left[d_{t+1}\right]}{P_{t}}+\frac{E_{t}\left[b_{t+1}\right]-\left(1+\bar{g}_{i t}\right) b_{t}}{P_{t}}=\bar{g}_{i t}+\frac{E_{t}\left[d_{t+1}\right]}{P_{t}}$, or $P_{t}=\frac{E_{t}\left[d_{t+1}\right]}{\bar{r}_{t}-\bar{g}_{i t}}$.
} 
the ERP and XRET1 provides support for the validity of the ICC as a proxy of expected return (Botosan and Plumlee (2005)).

A valid proxy of expected return should also be consistent with established asset pricing theory (for example, Litner 1965; Mossin 1966; Sharpe 1964; Modigliani and Miller 1958; Ross 1976; Berk 1995). I therefore test whether the expected risk premium (ERP) is positively correlated with market beta, leverage and default risk, and negatively correlated with market value of equity.

\section{Empirical Results}

As indicated above, my analysis has two steps. I first estimate the sample average of growth rate and valuation multiples based on equations (8), and (9)-(13) on an industry-year basis. Then, I compute the firm-specific cost of capital based on equation (14).

\subsection{Using I/B/E/S Forecasts of Earnings to Infer Expected Risk Premium}

I initially infer risk premium by using analysts' forecasts of earnings in equations (8), (9)-(13), and (14). In the next subsection, I introduce a method to adjust predictable analysts' forecast errors and then estimate risk premium.

\subsubsection{Average ICC, growth rate and valuation multiples for an industry-year portfolio}

My 5 industries are classified using the definitions downloaded from Ken French's website. To increase the observations for each of my 150 portfolios in an industry-year analysis, I use a two-year rolling window for 30-year over 1980-2009. ${ }^{28}$ To reduce nonstationarity and minimize the effects of endogeneity, I follow Ashton and Wang (2012)

\footnotetext{
${ }^{28}$ For example, for year 1980, I use forecasts of earnings for 1980 and 1981 and accounting data for 1979 and 1980. If industry classification is per Fama-French (1997), it needs more years rolling window to have sufficient observations for firms in some of the 48-industry each year.
} 
and deflate both sides of equation (8) by the price three months after the fiscal year-end to provide contemporaneity with the fiscal year-end reporting of book values and earnings. I use analysts' forecasts of one-year-ahead earnings per share as the dependent variable.

$<$ Insert Table 2 about here>

Table 2 reports the parameter estimates in the regression for each of 150 industry-year portfolios. Panel A shows the average of estimates for all 5-industries on a year-by-year basis. The sample size varies over the 30 years from a low of 1,682 firms in 1980 to a high of 4859 firms in 2006 over a two-year window. The average number of annual observations is 3,545. All of the $\delta_{1} \mathrm{~s}$ and $\delta_{2} \mathrm{~s}$ are positive as predicted. I also observe that $\delta_{1}$ and $\delta_{5}$ are highly significant with regard to explaining one-year-ahead earnings, confirming that prices lead earnings after controlling for current earnings and book values. I also note that current earnings $\left(\delta_{2}\right)$ are an important predictor of future earnings. Neither the coefficient of current book value $\left(\delta_{3}\right)$ nor the coefficient of lagged book value $\left(\delta_{4}\right)$ is statistically significant. Panel B shows the average of estimates for 30 years on an industry-by-industry basis. The results are consistent with Panel A. They confirm that prices lead earnings and that earnings are highly persistent. On average, five variables: current earnings, current and lagged prices, and current and lagged book values, together explain $38.6 \%$ of one-year-ahead of analysts' forecasts of earnings.

\section{<Insert Table 3 about here>}

In Table 3, I detail the estimates of cost of capital, growth rates, valuation multiples, accounting conservatism parameter, and risk premia for my 150 industry-year portfolios. Similar to Table 2, I report separate results on a year-by-year basis (Panel A) and on an industry-by-industry basis (Panel B). I observe that the annual mean cost of capital is $9.5 \%$ 
and the mean risk premium is $2.32 \%$ over $1980-2009$. I report risk premium based on tenyear U.S. government bond yields as a proxy for the risk-free rate. I find that the annual mean growth rate is $3.34 \%$. Consistent with prior literature, I also note a downward trend in the cost of capital, with the average falling from $12 \%$ between $1980-1990$ to $9.66 \%$ between 1991-2000, and finally to $6.48 \%$ between $2001-2009$. While the average long-run growth is $3.95 \%$ between 1980-2003, the annual growth rate is not statistically different from zero after 2004. However, as shown in Figure 1, the risk premium shows an upward trend between 2004-2009, reflecting the fact that the risk-free rate decreases more in magnitude compared to the mean ICC. This coincides with the recent financial and credit crisis, and investors demand a higher risk premium. As expected, valuation weight on book value $\left(\alpha_{1}\right)$ is greater than 1 except in 2 out of the 30 years. All valuation weights on earnings $\left(\alpha_{2}\right)$ are greater than zero and statistically significant at the $1 \%$ level. All conservatism parameters $(\lambda)$ are greater than zero. The mean conservatism parameter is 0.017 with t-statistic of 3.19 .

\section{<Insert Figure 1 about here>}

Figure 1 illustrates the trend in cost of capital, the risk premium and long-run growth. Results on an industry-by-industry basis shown in Panel B are similar.

\subsubsection{Firm-specific ICC and its relation with realized returns and risk factors}

Assigning the parameters estimated in the above analysis to each firm in the 150 industry-year portfolios, equation (14) delivers a firm-specific measure of the ICC. Following prior literature (e.g., Campbell, 1991; Vuolteenaho, 2002), I consider cash flow news (CFN) and discount rate news (DRN) when I examine the relation between the ICC and realized future stock returns. CFN equals actual earnings per share for year $t+1$ less analysts' forecasts of one-year-ahead earnings per share or 'earnings surprise', scaled by stock price at 
time $t$. DRN is an economy-wide discount rate news proxy, which is measured by the oneyear-ahead change in the yields of the five-year treasury constant maturity as of the month the expected return estimates (Easton and Monahan (2005); Botosan et al. (2012)). Following Fama and French (1989) and others, I also consider term spread and default spread. Term Spread is calculated as the difference between 10-Year US Treasury constant maturity rate and the 3-month US T-Bill yields. Default Spread is calculated as the difference between Moody's Seasoned Baa and Aaa Corporate Bond yields. Data on corporate bonds and US TBills/Bonds are obtained from the FRED database of the Federal Reserve Bank of St. Louis. If the implied rate of return is qualified as a proxy for the expected return, it may be reasonable to delete firm-year observations with the implied cost of capital less than the riskfree rate (Easton 2009). ${ }^{29}$ In my following analysis of the characteristics of expected return I eliminate such firm-year observations. My interest is in the association between excess oneyear-ahead realized returns (XRET1) and excess implied cost of capital or expected risk premium (ERP).

<Insert Table 4 about here>

Table 4 Panel A provides descriptive statistics pertaining to XRET1, ERP, and other risk proxies. Mean and median estimates of the expected risk premium are $4.7 \%$ and $3.5 \%$ respectively. ${ }^{30}$ While the median XRET1, $4.1 \%$ falls within the range of the expected risk premium, its standard deviation of $53.5 \%$ greatly exceeds the standard deviation of ERP, which equals $4.7 \%$. Panel A also provides descriptive statistics for proxies of cash flow news, discount rate news, term spread and default spread. CFN has a mean value of -0.044 , which is

\footnotetext{
${ }^{29}$ There are about $24 \%$ of firm-year observations with the implied cost of capital less than the risk-free rate. This includes the ICCs declined between 2001-2009. I note that 31\% of the firm-years in the Easton and Monahan (2005) sample (from 1981 to1998) have values of implied cost of equity capital below the risk-free rate. This suggests that the ICC is a downward biased measure of expected return. When I drop firm-year observations with the ICC less than zero instead of the risk-free rate, the main results are similar.

${ }^{30}$ If I keep firm-year observations with the ICC less than the risk-free rate but greater than 0 , then mean and median estimates of the ERP are $3.46 \%$ and $2.75 \%$ respectively. Note that the number of observations for XRET1 is smaller than that of ICCs since I require 12 consecutive monthly returns to calculate the annual return of a firm.
} 
statistically significantly negative at the $1 \%$ level, suggesting analysts' optimism. The mean of DRN is also significantly negative at -0.248 , indicating an annual decline in the risk-free rate over my sample period. The means of term spread and default spread are 1.685 and 1.095 respectively. The statistics also describe a sample where average market risk is comparable with that of the market portfolio with a mean (median) beta of $1.058(0.984)$ and a mean (median) debt-to-equity ratio of $69.9 \%(26 \%)$.

Table 4 Panel B presents pair-wise correlations among a set of variables applied in my regression analysis. It shows that the proxy of expected risk premium ERP correlates positively with XRET1 with $\rho=0.143$. As expected, the correlation between XRET1 and CFN is positive ( $\rho=0.181)$, and that between XRET1 and DRN is negative $(\rho=-0.049)$. These correlations are significant at the $1 \%$ level, suggesting cash flow news and discount rate news may play an important role in explaining realized returns. Consistent with prior literature, XRET1 is positively related to leverage and beta, and is negatively related to the size (Fame and French $(1992,1993,1995))$. In contrast to XRET1, there is a strong negative correlation between ERP and cash flow news (CFN). The correlation between ERP and discount rate news is positive but not statistically significant. The expected risk premium ERP also correlates positively with beta, leverage, term spread and default spread, and negatively with firm size in a theoretically predictable manner.

Table 4 Panel $\mathrm{C}$ documents ICC's out-of-sample predictive ability with respect to future stock returns by sorting firms into quintiles of implied cost of capital distribution at the end of March of each year. For each portfolio, I calculate the value-weighted mean buy-andhold return for the next 12 months. I also calculate hedge returns as the difference in returns between the top (Q5) and bottom (Q1) quintiles of ICCs. It shows that my measure ICC 
exhibits a monotonic relation with future realized returns. The difference in returns between the top and bottom quintiles of ICC, Q5-Q1, is equal to 8.2\%.

Next, I examine the excess return predictive ability of expected risk premium, ERP, at the firm level. I also investigate the cross-sectional relation between a set of conventional risk characteristics and ex post realized return. All regressions are based on a pooled sample, with year fixed effects and standard errors clustered by firm and year as in Petersen (2009), and Gow, Ormazabal and Taylor (2010). Table 5 reports coefficients and their t-statistics (in brackets) for these regressions.

\section{<Insert Table 5 about here>}

Notably, no matter what risk proxies I control for, the implied risk premium has significant explanatory power to excess one-year-ahead realized returns. CFN and default spread have a significant incremental role in explaining future realized returns. Specifically, the result of univariate regression of excess realized returns on expected risk premium in Table 5 column 2 shows that ERP is positively related to XRET1 with a coefficient of 1.8 , which is not statistically different from 1 as indicated in column 8 . When I include my proxies for cash flow news and discount rate news in the regression, it shows a strong positive relation between excess realized returns and cash flow news. Adjusted R-squareds increase from $2.04 \%$ to $7.15 \%$. I also find from column 9 that the slope increases to 2.44 with a t-statistic of 2.64, indicating the coefficient of implied risk premium is statistically different from 1 . When I include term spread and default spread, the result is similar. The adjusted Rsquareds increase from $2.04 \%$ to $8.68 \%$. This result is consistent with my expectation and with results documented in Voulteenaho (2002) and Botosan et al. (2012). While XRET1 being positively related to beta and leverage, and negatively related to firm size accords with expectations, neither market beta nor leverage is significantly related to excess future realized returns if book-to-price is included in the regression. When including book-to-price in my 
analysis, both term spread and default spread have the correct signs but are not statistically significant. The coefficient of book-to-price itself is positive and highly significant.

Given the inputs of accounting risk proxies when I infer the expected return, I examine the relation between ERP and the CAPM beta, size, leverage, total risk, term spread and default spread. Based on prior empirical studies on the cross sectional determinants of returns, I expect the cost of capital to be positively associated with beta, leverage, standard deviation of annual return and risk spreads, and to be negatively associated with firm size.

\section{<Insert Table 6 about here>}

Table 6 shows that the results of univariate and multivariate regressions of the expected risk premium on market beta, firm size and leverage are all in the theoretically predicted directions. Specifically, the expected risk premium is significantly positively related to beta and leverage, but negatively related to firm size. However, when I control for total risk, there is an insignificant negative relation between the implied risk premium and beta. The total risk itself is strongly positively related to EPR, reflecting a property that the I/B/E/S analysts' forecasts taking into account more total risk than the firm's systematic risk. In addition, the coefficient of beta is very stable in magnitude whether I use univariate or multivariate regressions if excluding total risk. When I include term spread and default spread into my regressions, I find that default spread is statistically significantly related to the implied risk premium. However, term spread shows a negative relation though it is not statistically significant. When I include ratio book-to-price as an explanatory variable, adjusted R-squareds increase significantly. This is not surprising since $\mathrm{B} / \mathrm{P}$ is an input when I infer the ICC. I can observe a clear spurious effect when earnings yield and forward earnings yield are included in my regression analysis. The adjusted R-squareds are nearly 59\%. I also 
note that the coefficient of book-to-price is negative but not statistically significant when I control for both earnings yield and forward earnings yield.

\subsection{Using Adjusted Forecasts to Infer Risk Premium}

Analysts' forecast errors are believed to weaken the association between the implied cost of capital and realized returns. To mitigate the effect of analysts' bias, I adjust the consensus forecasts for predictable errors (Hughes, Liu and Su (2008)). Earnings forecasting model (8) can be used for my purpose.

Following Gode and Mohanram (2012), I measure realized earnings forecast errors by the difference between realized earnings per share and expected earnings per share scaled by stock price. ${ }^{31}$ Consistent with equation (8), I regress the one-year-ahead realized earnings forecast errors (FERR1) on earnings-to-price $\left(\frac{e_{t}}{P_{t}}\right)$, book-to-price $\left(\frac{b_{t}}{P_{t}}\right)$, lagged book-to-price $\left(\frac{b_{t-1}}{P_{t}}\right)$ and lagged price to price $\left(\frac{P_{t-1}}{P_{t}}\right)$, then I multiply the coefficients from one-year lagged regressions of FERR 1 on the constant, $\frac{e_{t}}{P_{t}}, \frac{b_{t}}{P_{t}}, \frac{b_{t-1}}{P_{t}}$ and $\frac{P_{t-1}}{P_{t}}$ with the realized values of these variables, $P_{t}, e_{t}, b_{t} b_{t-1}, P_{t-1}$, to obtain predicted forecast errors. To avoid look-ahead bias, I run annual regressions of FERR1 at the end of year t on these factors as of the end of year $t$ 1. For example, I regress FERR1 at the end of 1979 on the observable factors at the end of 1978, then I use these regression coefficients and the observable factors as of the end of 1979 to predict the forecast error for earnings expected at the end of 1980, and so on. The adjusted

\footnotetext{
${ }^{31}$ Based on prior literature, Gode and Mohanram (2012) identify the following factors to predict forecast errors: accounting accruals, book-to-market ratio, earnings-to-price, long-term growth from IBES, sales growth, changes in gross PP\&E, past returns and revision in analyst forecasts.
} 
forecasts of earnings are then equal to analysts' forecasts of earnings subtracted by the forecast errors.

Using adjusted forecasts of earnings, I can repeat my analysis above to estimate the average growth rate, valuation multiples and conservatism parameter, $\bar{g}_{i t}, \bar{\alpha}_{1, i t}, \bar{\alpha}_{2, i t}$ and $\bar{\lambda}_{i, t}$, via equation (8). Equation (14) then gives firm-specific expected rate of returns when $E\left[e_{t+1}\right]$ is replaced by the adjusted forecasts of earnings.

\section{$<$ Insert Table 7 about here>}

Table 7 Panel A provides descriptive statistics pertaining to XRET1, ERP, and other risk proxies. Mean and median estimates of the expected risk premium are $6.4 \%$ and $3.9 \%$ respectively. ${ }^{32}$ While the median XRET1, 5.2\% falls within the range of the expected risk premium, its standard deviation of $56 \%$ greatly exceeds the standard deviation of ERP, which equals to $7.9 \%$. Panel A also provides descriptive statistics for proxies of my cash flow news, discount rate news, term spread and default spread. Table 7 Panel B shows the correlation between the implied risk premium and one-year ahead excess realized returns and other risk characteristics. The correlations between ERP and XRET1, beta and term spread are indeed improved relative to ERP estimated from unadjusted forecasts of earnings. Table 7 Panel C reports the ICC's out-of-sample predictive ability with respect to future stock returns by sorting firms into quintiles of implied cost of capital distribution at the end of March of each year. For each portfolio, I calculate the mean buy-and-hold return for the next 12 months. After adjusting forecast errors, my measure ICC again exhibits a monotonic relation with future realized returns. The difference in returns between the top and bottom quintiles of ICC, Q5-Q1, increases to $10.2 \%$.

$<$ Insert Table 8 about here>

\footnotetext{
${ }^{32}$ Note that numbers of observations are reduced because there are more firm-year ICCs less than the risk-free rate when I use adjusted forecasts of earnings in estimating ICCs.
} 
The result of univariate regression of excess realized returns (XRET1) on expected risk premium (ERP) in Table 8 column 2 shows that ERP is positively related to XRET1 with coefficient of 1.31 , which is not statistically different from 1 as indicated in column 8 . The adjusted R-squared is improved relative to the ICC based on unadjusted forecasts of earnings. The results of multivariate regressions are similar to those when I use unadjusted forecasts of earnings. When I include my proxies for cash flow and discount rate news in the regression, I find the slope increases to 1.73 and CFN has significant incremental explanatory power. The adjusted R-squared increases from $2.54 \%$ to $7.34 \%$. Columns 9 and 10 suggest that I cannot reject the hypothesis that the slope is equal to 1 even if I include unexpected new information, term spread and default spread. While XRET1 is positively related to beta and negatively related to firm size accord with expectations, they are not statistically significant when I control for my proxy for the implied risk premium. While it shows strong positive relations between realized returns and cash flow news and default spread, the relations between future realized returns and discount rate news and term spread are not significant. When including book-to-price in my analysis, however, the coefficient of leverage is not statistically significant, although it still has the correct sign. The coefficient of book-to-price itself is positive and highly significant.

<Insert Table 9 about here>

Table 9 shows that the results of univariate and multivariate regressions of expected risk premium on market beta, firm size, leverage, and other risk characteristics after I adjust forecasts of earnings. The results confirm and strengthen my findings that market beta is significantly positively related to the implied risk premium. Moreover, the expected risk premium is significantly positively related to book-to-price, leverage and default spread, and negatively related to firm size. The coefficient of term spread is positive though not significant. Beta is now positively related to the implied risk premium when I control for 
firm's total risk, which itself is strongly positively related to EPR. It indicates that the adjusted forecasts of earnings still reflect more total risk than the firm's systematic risk. When I include book-to-price as an explanatory variable, the adjusted R-squareds are increased significantly. Again, the spurious effect is clear when earnings yield and forward earnings yield are included in my regression analysis, and the adjusted R-squareds are increased to more than $62 \%$. I also note that the coefficient of book-to-price is now positive and statistically significant when I control for both earnings yield and forward earnings yield. It suggests that the relation between the ICC and B/P depends on the measurement of oneperiod ahead earnings when including forward earnings yield in the regression.

\section{Conclusion}

An increasing number of studies in finance and accounting use the implied cost of capital as a proxy for expected stock return. The evidence suggests that this proxy offers significant promise towards an understanding of puzzles in empirical asset pricing. However, existing implied cost of capital models rely on a dividend payout policy in a forecast period and multiperiod ahead forecasts of earnings, and/or assume a terminal growth rate to truncate infinite future cash flows generated from an equity share. The validity of alternative proxies is often challenged from the following two aspects. There is an insignificant or negative relation between some proxies of the ICC and future realized returns, and there is an inconsistent relation to prior literature in asset pricing between some proxies and established risk characteristics.

This paper extends the Ashton and Wang (2012) approach to infer a firm-specific measure of the ICC. The approach allows one to estimate simultaneously the firm-specific implied cost of capital and growth rates of the NPV of future investments for industry-year 
portfolios. It requires only one-year-ahead forecasts of earnings, and dividend payout policy is irrelevant. It explicitly shows that the firm-specific measure of the implied cost of capital is intrinsically linked to commonly used firm-specific accounting ratios including book-tomarket, (forward) earnings yield, dividend-to-price as well as growth and past returns in an analytic form. The expression yields the insight that expected returns are associated with the risk that is related to uncertainty about future growth of the net present value in future investments. This provides an explanation as to why the book-to-price $(\mathrm{B} / \mathrm{P})$ ratio may be useful for explaining expected stock returns. Forward earnings yield is identified as an omitted factor in the standard asset pricing models and the Fama and French factor model. It also provides an alternative explanation as to what contributes to the momentum premium.

I show that my proxy of expected return is significantly positively associated with future realized stock returns. My measure remains significantly positively related to future realized stock returns even after controlling for commonly used risk proxies. My measure also significantly correlates with commonly used risk characteristics, such as the CAPM beta, size, leverage and default spread, in a theoretically predicted manner. 


\section{REFERENCES}

Ashton, D. and P. Wang, 2012, Terminal valuations, growth rates and the implied cost of capital, Review of Accounting Studies, forthcoming, DOI 10.1007/s11142-012-9208-5.

Ball, R., 1978, Anomalies in relationships between securities' yields and yield-surrogates, Journal of Financial Economics 6, 103-126.

Beaver, W., P. Kettler and M. Scholes, 1970, The association between market determined and accounting determined risk measures, The Accounting Review (October), 654-681.

Berk, J., 1995, A critique of size-related anomalies, Review of Financial Studies (Summer), 275-86.

Berk, J., R. Green, and V. Naik, 1999, Optimal investment, growth options, and security returns, Journal of Finance 54, 1153-1608.

Botosan, C., and M.A. Plumlee, 2005, Assessing alternative proxies for the expected risk premium, The Accounting Review 80, 21-53.

Botosan, C., M. A. Plumlee, and H. J. Wen, 2012, The relation between expected returns, realized returns, and firm risk characteristics, Contemporary Accounting Research, forthcoming.

Campbell, J., 1991, A variance decomposition for stock returns, The Economic Journal 101, 157-179.

Campbell, J., and R. Shiller, 1988, Stock prices, earnings, and expected dividends, Journal of Finance 43, 661-676.

Campbell, J., and R. Shiller, 1998, Valuation ratios and the long-run stock market outlook, Journal of Portfolio Management 24, 11-26.

Campbell, J., and S. Thomson, 2008, Predicting the equity premium out of sample: can anything beat the historical average? Review of Financial Studies 21, 1509-1531.

Chan, K., A. Hameed, and W. Tong, 2000, Profitability of momentum strategies in international equity markets, Journal of Financial and Quantitative Analysis 35, 153172.

Chava, S., and A. Purnanadam, 2010, Is default risk negatively related to stock returns? Review of Financial Studies 23, 2523-2559.

Chen, K.C. W., Z. Chen and K. C. Wei. 2011. Agency costs of free cash flow and the effect of shareholder rights on the implied cost of equity capital, Journal of Financial and Quantitative Analysis 46, 171-207.

Chen, Z., Y. Huang and K.C. Wei, 2012, Executive pay disparity and the cost of equity capital, Journal of Financial and Quantitative Analysis, forthcoming. 
Claus, J., and J. Thomas, 2001, Equity premia as low as three percent? evidence from analysts' earnings forecasts for domestic and international stock markets, The Journal of Finance 56, 1629-1666.

Cooper, M., H. Gulen, and M. Schill, 2008, Asset growth and the cross-section of stock returns, Journal of Finance 63, 1609-1651.

Damodaran, A., 2002, Damodaran on valuation (2nd ed.). New York: Wiley.

Easton, P.D., 2004, PE ratios, PEG ratios, and estimating the implied expected rate of return on equity capital, The Accounting Review 79, 73-96.

Easton, P.D., 2009, Estimating the cost of capital implied by market price and accounting data, Foundations and Trends in Accounting 2, 241-364.

Easton, P.D., G. Taylor, P. Shroff, and T. Sougiannis, 2002, Using forecasts of earnings to simultaneously estimate growth and the rate of return on equity investment, Journal of Accounting Research 40, 657-676.

Easton, P.D. and S. Monahan, 2005, An evaluation of accounting-based measures of expected returns, Accounting Review 80, 501-38.

Easton, P.D, and G. Sommers, 2007, Effect of analysts' optimism on estimates of the expected rate of return implied by earnings forecasts, Journal of Accounting Research 45, 983-1016.

Elton, E., 1999, Expected return, realized return and asset pricing tests, Journal of Finance 54, 1199-1220.

Fama, E., and K. French, 1988, Dividend yields and expected stock returns, Journal of Financial Economics 22, 3-25.

Fama, E., and K. French, 1989, Business conditions and expected returns on stocks and bonds, Journal of Financial Economics 25, 23-49.

Fama, E., and K. French, 1992, The cross-section of expected stock returns, Journal of Finance 47, 427-465.

Fama, E., and K. French, 1993, Common risk factors in the returns of stocks and bonds, Journal of Financial Economics 33, 3-56.

Fama, E., and K. French, 1997, Industry costs of equity, Journal of Financial Economics 43, $153-193$.

Fama, E., and K. French, 2006, Profitability, investment and average returns, Journal of Financial Economics 82, 491-518.

Feltham, G., and J. Ohlson, 1995, Valuation and clean surplus accounting for operating and financial activities, Contemporary Accounting Research 11, 689-731.

Feltham, G., and J. Ohlson, 1996, Uncertainty resolution and the theory of depreciation measurement, Journal of Accounting Research 34, 209-234.

Gebhardt, W., C. Lee, and B. Swaminathan, 2001, Toward an implied cost of capital, Journal of Accounting Research 39, 135-176. 
Gode, D., and P. Mohanram, 2003, Inferring cost of capital using the Ohlson-Juettner model, Review of Accounting Studies 8, 339-431.

Gode., D., and P. Mohanram, 2012, Evaluating implied cost of capital estimates after removing analyst forecasts errors, Review of Accounting Studies, forthcoming.

Gordon, J., and M. Gordon, 1997, The finite horizon expected return model, Financial Analysts Journal May/June, 52-61.

Gow, I.D., G. Ormazabal, and D.J. Taylor, 2010, Correcting for cross-sectional and timeseries dependence in accounting research, The Accounting Review 85, 483-512.

Hail, L. and C. Leuz, 2006, International differences in cost of capital: Do legal institutions and securities regulation matter? Journal of Accounting Research 44, 485-531.

Hail, L. and C. Leuz, 2009, Cost of capital effects and changes in growth expectations around U.S. cross-listings, Journal of Financial Economics 93, 428-454.

Hou, K., and D. Robinson, 2006, Industry concentration and average stock returns, Journal of Finance 61, 1927-1956.

Hou, K., M. van Dijk and Y. Zhang, 2012, The implied cost of capital: a new approach, Journal of Accounting and Economics, Forthcoming.

Hughes, J., J. Liu, and W. Su, 2008, On the relation between predictable market returns and predictable analyst forecast errors, Review of Accounting Studies 13, 266-291.

Jegadeesh, N. and S. Titman, 1993, Returns to buying winners and selling losers: implications for stock market efficiency, Journal of Finance 48, 65-91.

Jegadeesh, N. and S. Titman, 2001, Profitability of momentum strategies: an evaluation of alternative explanations, Journal of Finance 56, 699- 720.

Kaplan, S.N. and R.S. Ruback, 1995, The valuation of cash flow forecasts: an empirical analysis, The Journal of Finance 50, 1059-1093.

Lee, C. M. C., D. Ng, and B. Swaminathan, 2009, Testing international asset pricing models using implied costs of capital, Journal of Financial and Quantitative Analysis 44, 307-335.

Lee, C. M. C., E.C. So and C.Y. Wang, 2011, Evaluating Implied Cost of Capital Estimates. Stanford University working paper.

Liew, J., and M. Vassalou, 2000, Can book-to-market, size and momentum be risk factors that predict economic growth? Journal of Financial Economics 57, 221-245.

Lintner, J., 1965, The valuation of risk assets and the selection of risky investments in stock portfolios and capital budgets, The Review of Economics and Statistics 47, 13-37.

Liu, J., D. Nissim, and J. Thomas, 2002, Equity valuation using multiples, Journal of Accounting Research 40, 135-172.

Mossin, J., 1966, Equilibrium in a capital asset market, Econometrica 341, 768-83. 
Miller, M., and F. Modigliani, 1961, Dividend policy, growth and the valuation of shares, Journal of Business 34, 411-433.

Modigliani, F. and M. Miller, 1958, The expected cost of equity capital, corporation finance, and the theory of investment, American Economic Review (June), 261-97.

Nekrasov, A., and M. Ogneva, 2011, Using earnings forecasts to simultaneously estimate firm-specific cost of equity and long-term growth, Review of Accounting Studies 16, 414-457.

Okunev J., and D. White, 2003, Do momentum based strategies still work in foreign currency markets? Journal of Financial and Quantitative Analysis 38, 425-447.

Ohlson, J., 1995, Earnings, book values, and dividends in security valuation, Contemporary Accounting Research 11, 661-687.

Ohlson, J., 2005, A simple model relating the expected return (risk) to the book-to-market and the forward earnings-to-price ratios, Working paper, http://ssrn.com/abstract=683304.

Ohlson, J., and B.E. Juettner-Nauroth, 2005, Expected EPS and EPS growth as determinants of value, Review of Accounting Studies 10, 349-365.

Pastor, L., M. Sinha, and B. Swaminathan, 2008, Estimating the intertemporal risk-return tradeoff using the implied cost of capital, The Journal of Finance 63, 2859-2897.

Penman, S., 2010, Financial Statement Analysis and Security Valuation, 4th ed. New York, The McGraw-Hill Companies.

Penman, S., and F. Reggiani, 2012, Returns to buying earnings and book value: accounting for growth and risk, Working paper, http://ssrn.com/abstract=1536043.

Penman, S., F. Reggiani, S.A. Richardson and I. Tuna, 2011, A characteristic model for asset pricing, Working paper, London Business School.

Petersen, M.A., 2009, Estimating standard errors in finance panel data sets: comparing approaches, The Review of Financial Studies 22, 435-480.

Pratt, S. P. and A.V. Niculita, 2007, Valuing a business: the analysis and appraisal of closely held companies, Fifth edition, McGraw-Hill.

Richardson, S., I. Tuna, and P. Wysocki, 2010, Accounting anomalies and fundamental analysis: a review of recent research advances, Journal of Accounting and Economics 50, 410-454.

Ross, S., 1976, The arbitrage theory of capital asset pricing, Journal of Economic Theory 13, 341-60.

Rouwenhorst, K., 1998, International momentum strategies, Journal of Finance 53, 267-284.

Sharpe, W., 1964, Capital asset price: a theory of market equilibrium under conditions of risk, Journal of Finance 19: 425-42.

Vassalou, M., 2003, News related to future GDP growth as a risk factor in equity returns, Journal of Financial Economics 68, 47-73.

Vuolteenaho, T., 2002, What drives firm-level stock returns? Journal of Finance 57, 233-264. 
Walker M. and P. Wang, 2003, Towards an understanding of profitability analysis within the residual income valuation framework, Accounting and Business Research 33, 235-246.

Weiss D, P.A. Naik and C-L Tsai, 2008, Extracting forward-looking information from security price: a new approach, The Accounting Review 83(4), 1101-1124. 


\section{Figure 1}

The Relation Between Estimates of the Cost of Capital, Growth Rate and Risk Premium

This figure shows the trends of the implied cost of capital, risk premium and growth rate over 1980-2009. Risk premium is equal to the difference between the implied cost of capital and 10 -year US government bond yields. Growth is the expected growth rate of the NPV of future investment implied in the analysts' forecasts of earnings.

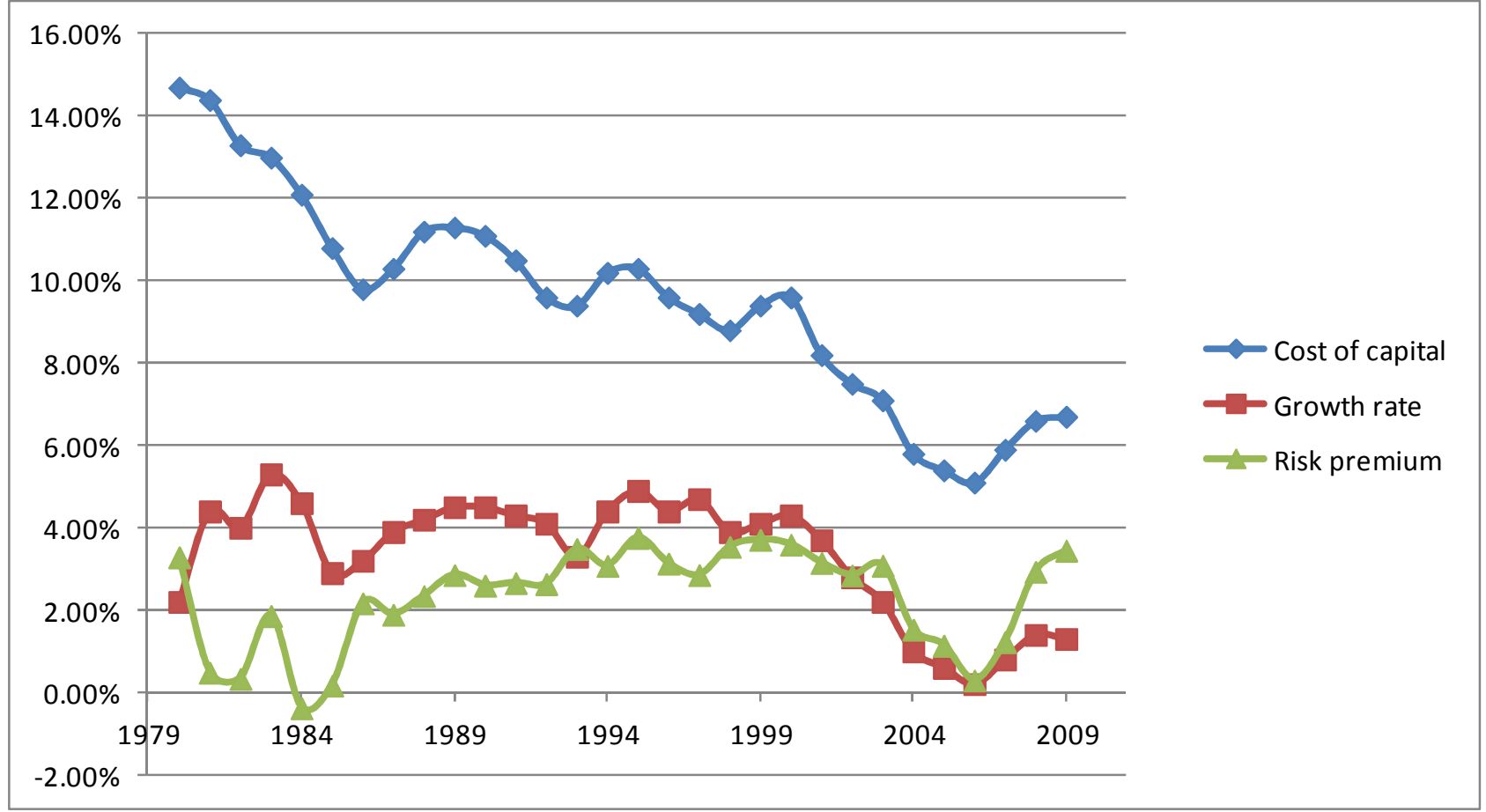


Table 1

\section{Sample Descriptive Statistics and Correlation Matrix}

Panel A shows descriptive statistics for 60,170 firm-years between 1980 and 2010 . Observations outside the $1^{\text {st }}$ and $99^{\text {th }}$ percentiles for book value, earnings, price and number of shares outstanding are deleted. The mean, standard deviation (stdev), median, and $1 \%$ and $99 \%$ are reported. feps is the median consensus forecasts of earnings at the first month after the corresponding I/B/E/S-reported prior-year earnings announcements. Price (P) is stock price 3-months after the fiscal year-end. bps and eps are book value per share and earnings per share respectively. Earnings are net income per share before extraordinary items. B/P and E/P are the book-to-price ratio and earnings-toprice ratio respectively. FE/P is one-year-ahead I/B/E/S consensus forecasts of earnings scaled by price. Mktcap is market capitalization 3-months after the fiscal year-end. LEV is total debt divided by the firm's market capitalization 3 months after the fiscal year-end.

Panel B shows the annual cross-sectional correlations for 60,170 firm-year observations. The upper (lower) right triangle of the matrix shows Spearman (Pearson) correlations.

\begin{tabular}{|c|c|c|c|c|c|c|c|c|c|}
\hline \multicolumn{10}{|c|}{ Panel A: Sample Statistics } \\
\hline & feps & $\mathrm{P}$ & bps & eps & $\mathrm{B} / \mathrm{P}$ & $\mathrm{E} / \mathrm{P}$ & $\mathrm{FE} / \mathrm{P}$ & Mktcap & Lev \\
\hline $\mathrm{N}$ & 60170 & 60170 & 60170 & 60170 & 60170 & 60170 & 60170 & 60170 & 60170 \\
\hline mean & 1.108 & 16.630 & 11.180 & 1.091 & 0.840 & 0.048 & 0.067 & 1683.000 & 0.884 \\
\hline stdev & 1.035 & 12.730 & 22.650 & 3.177 & 2.342 & 0.318 & 0.077 & 4759.000 & 5.718 \\
\hline $\mathrm{p} 1$ & -0.990 & 1.338 & 0.549 & -3.078 & 0.072 & -0.628 & -0.193 & 12.020 & 0.000 \\
\hline p25 & 0.410 & 7.000 & 3.693 & 0.194 & 0.344 & 0.022 & 0.045 & 108.100 & 0.040 \\
\hline p50 & 0.900 & 13.380 & 7.148 & 0.703 & 0.557 & 0.054 & 0.068 & 335.000 & 0.240 \\
\hline p75 & 1.600 & 22.820 & 12.610 & 1.447 & 0.859 & 0.084 & 0.094 & 1172.000 & 0.720 \\
\hline p99 & 4.550 & 58.750 & 73.990 & 10.020 & 5.524 & 0.613 & 0.245 & 23079.000 & 9.442 \\
\hline \multicolumn{10}{|c|}{ Panel B: Correlation Matrix (Pearson Bottom; Spearman Top) } \\
\hline & feps & $\mathrm{P}$ & bps & eps & $\mathrm{B} / \mathrm{P}$ & $\mathrm{E} / \mathrm{P}$ & $\mathrm{FE} / \mathrm{P}$ & Mktcap & Lev \\
\hline feps & & 0.762 & 0.695 & 0.829 & 0.002 & 0.489 & 0.485 & 0.437 & 0.193 \\
\hline $\mathrm{P}$ & 0.716 & & 0.635 & 0.648 & -0.313 & 0.105 & -0.104 & 0.642 & -0.037 \\
\hline bps & 0.275 & 0.240 & & 0.629 & 0.471 & 0.335 & 0.228 & 0.289 & 0.367 \\
\hline eps & 0.383 & 0.295 & 0.794 & & 0.036 & 0.744 & 0.396 & 0.388 & 0.161 \\
\hline $\mathrm{B} / \mathrm{P}$ & -0.021 & -0.094 & 0.641 & 0.434 & & 0.300 & 0.413 & -0.366 & 0.494 \\
\hline $\mathrm{E} / \mathrm{P}$ & 0.178 & 0.073 & 0.501 & 0.627 & 0.673 & & 0.683 & 0.038 & 0.254 \\
\hline $\mathrm{FE} / \mathrm{P}$ & 0.439 & -0.015 & 0.073 & 0.156 & 0.066 & 0.282 & & -0.154 & 0.364 \\
\hline Mktcap & 0.286 & 0.431 & 0.045 & 0.095 & -0.051 & 0.014 & -0.019 & & -0.054 \\
\hline Lev & 0.002 & -0.046 & 0.362 & 0.261 & 0.653 & 0.497 & 0.050 & -0.014 & \\
\hline
\end{tabular}


Table 2

\section{Regressing Forecasted Earnings on Price, Earnings, Book Value, Lagged Book Value and Lagged Price}

Table 2 reports the regression coefficients (t-values) of $\delta_{\mathrm{i}}(\mathrm{i}=1-5)$ in $\frac{f e p s_{t+1}}{P_{t}}=\delta_{1}+\delta_{2} \frac{e_{t}}{P_{t}}+\delta_{3} \frac{b_{t}}{P_{t}}+\delta_{4} \frac{b_{t-1}}{P_{t}}+\delta_{5} \frac{P_{t-1}}{P_{t}}+\varepsilon_{t+1}$ for each of the 150 industry-year portfolios based on the estimates in a two-year rolling window between 1980-2009. Industry classification for 5-industries is per Ken French's website. Observations with any of the dependent or independent variables in the top and bottom $1 \%$ of observations are removed to reduce the effects of outliers. feps $s_{t+1}$ is the median consensus forecasts of earnings at the first month after the corresponding I/B/E/S-reported prior-year earnings announcements; $P_{t}$ and $P_{t-1}$ are the contemporary stock price and lagged stock price respectively; $b_{t}$ and $b_{t-1}$ are the contemporary book value of equity and lagged book value of equity respectively; $e_{t}$ is net income before extraordinary items. $\mathrm{N}$ is the number of observations in a two-year rolling window. The descriptive statistics, including mean, standard deviation, minimum, lower quartile, median, upper quartile and maximum, are also reported. Panels A and B report the results on a year-by-year basis and industry-by-industry basis respectively.

\begin{tabular}{|c|c|c|c|c|c|c|c|c|c|c|c|c|}
\hline \multicolumn{13}{|c|}{ Panel A: by year, mean value for 5-industry } \\
\hline Year & $\delta_{1}$ & t-stat & $\delta_{2}$ & t-stat & $\delta_{3}$ & t-stat & $\delta_{4}$ & t-stat & $\delta_{5}$ & t-stat & $\operatorname{adj}-R^{2}$ & $\mathrm{~N}$ \\
\hline $79-80$ & 0.046 & 6.25 & 0.469 & 7.00 & 0.006 & 0.18 & 0.009 & 0.66 & 0.020 & 2.20 & $54.06 \%$ & 1682 \\
\hline $80-81$ & 0.045 & 6.84 & 0.392 & 6.70 & 0.017 & 0.51 & 0.011 & 0.61 & 0.015 & 2.47 & $52.63 \%$ & 1812 \\
\hline $81-82$ & 0.040 & 6.62 & 0.363 & 6.93 & -0.005 & -0.29 & 0.033 & 1.44 & 0.019 & 3.46 & $51.29 \%$ & 2013 \\
\hline $82-83$ & 0.031 & 6.26 & 0.375 & 7.70 & 0.030 & 0.47 & 0.002 & 0.89 & 0.019 & 3.55 & $51.76 \%$ & 2284 \\
\hline $83-84$ & 0.034 & 6.44 & 0.359 & 7.68 & 0.043 & 1.43 & -0.012 & -0.04 & 0.015 & 3.16 & $47.78 \%$ & 2411 \\
\hline $84-85$ & 0.037 & 6.57 & 0.343 & 7.80 & -0.011 & 0.10 & 0.032 & 1.26 & 0.015 & 2.87 & $41.19 \%$ & 2491 \\
\hline $85-86$ & 0.037 & 6.56 & 0.296 & 6.91 & -0.024 & -0.57 & 0.049 & 1.96 & 0.010 & 1.53 & $33.29 \%$ & 2572 \\
\hline $86-87$ & 0.032 & 5.64 & 0.279 & 6.50 & -0.008 & 0.04 & 0.039 & 1.37 & 0.014 & 2.54 & $31.95 \%$ & 2572 \\
\hline $87-88$ & 0.038 & 5.97 & 0.306 & 6.84 & -0.008 & 0.24 & 0.039 & 1.23 & 0.011 & 2.21 & $32.95 \%$ & 2631 \\
\hline $88-89$ & 0.030 & 4.75 & 0.287 & 6.66 & 0.023 & 1.18 & 0.011 & 0.63 & 0.019 & 3.26 & $35.22 \%$ & 2840 \\
\hline $89-90$ & 0.026 & 4.91 & 0.286 & 6.21 & 0.019 & 0.69 & 0.016 & 0.85 & 0.022 & 4.24 & $38.75 \%$ & 2916 \\
\hline $90-91$ & 0.029 & 5.92 & 0.294 & 6.40 & 0.005 & -0.04 & 0.027 & 1.48 & 0.017 & 3.31 & $39.86 \%$ & 2942 \\
\hline $91-92$ & 0.037 & 7.32 & 0.272 & 5.99 & 0.009 & 0.55 & 0.022 & 0.94 & 0.005 & 1.15 & $33.63 \%$ & 3085 \\
\hline $92-93$ & 0.031 & 6.94 & 0.316 & 6.74 & -0.007 & 0.25 & 0.032 & 1.11 & 0.011 & 2.77 & $36.99 \%$ & 3362 \\
\hline $93-94$ & 0.028 & 6.19 & 0.328 & 7.24 & -0.005 & -0.14 & 0.034 & 1.56 & 0.013 & 2.84 & $36.47 \%$ & 3761 \\
\hline $94-95$ & 0.028 & 6.06 & 0.287 & 6.57 & 0.025 & 0.94 & 0.009 & 0.68 & 0.013 & 2.79 & $34.18 \%$ & 4203 \\
\hline $95-96$ & 0.027 & 7.08 & 0.266 & 6.76 & 0.018 & 0.84 & 0.015 & 0.75 & 0.013 & 2.92 & $32.16 \%$ & 4549 \\
\hline $96-97$ & 0.026 & 7.61 & 0.264 & 6.56 & 0.001 & 0.32 & 0.034 & 1.39 & 0.011 & 2.59 & $30.68 \%$ & 4744 \\
\hline $97-98$ & 0.022 & 7.57 & 0.324 & 8.74 & -0.013 & -0.20 & 0.042 & 1.89 & 0.013 & 3.94 & $37.85 \%$ & 4734 \\
\hline $98-99$ & 0.019 & 5.44 & 0.376 & 10.35 & -0.019 & -0.73 & 0.047 & 2.65 & 0.015 & 4.57 & $43.55 \%$ & 4444 \\
\hline $99-00$ & 0.025 & 6.77 & 0.345 & 7.90 & -0.018 & -0.36 & 0.049 & 2.03 & 0.012 & 3.45 & $39.41 \%$ & 4088 \\
\hline 00-01 & 0.032 & 7.35 & 0.298 & 7.22 & 0.002 & 0.46 & 0.025 & 0.76 & 0.001 & 0.57 & $33.44 \%$ & 4058 \\
\hline $01-02$ & 0.033 & 8.45 & 0.286 & 7.41 & 0.011 & 0.63 & 0.009 & 0.30 & 0.001 & 0.59 & $32.83 \%$ & 4217 \\
\hline
\end{tabular}




\begin{tabular}{|c|c|c|c|c|c|c|c|c|c|c|c|c|}
\hline $02-03$ & 0.027 & 8.41 & 0.329 & 9.13 & 0.003 & 0.68 & 0.011 & 0.08 & 0.008 & 2.86 & $40.77 \%$ & 4361 \\
\hline 03-04 & 0.032 & 9.54 & 0.343 & 8.38 & 0.007 & 0.60 & 0.000 & -0.04 & 0.001 & 0.18 & $40.10 \%$ & 4670 \\
\hline $04-05$ & 0.032 & 8.58 & 0.312 & 7.56 & 0.013 & 0.52 & -0.008 & -0.19 & 0.002 & 0.42 & $35.82 \%$ & 4842 \\
\hline $05-06$ & 0.031 & 7.69 & 0.305 & 7.67 & -0.004 & 0.13 & 0.006 & 0.03 & 0.004 & 0.91 & $33.93 \%$ & 4859 \\
\hline 06-07 & 0.027 & 7.28 & 0.339 & 8.81 & -0.015 & -0.28 & 0.020 & 0.41 & 0.007 & 2.15 & $37.04 \%$ & 4822 \\
\hline 07-08 & 0.029 & 7.58 & 0.316 & 9.20 & -0.013 & -0.95 & 0.022 & 1.30 & 0.008 & 2.28 & $34.28 \%$ & 4262 \\
\hline 08-09 & 0.034 & 9.50 & 0.276 & 8.49 & 0.002 & 0.14 & 0.006 & 0.23 & 0.007 & 2.03 & $33.00 \%$ & 4123 \\
\hline Average & 0.032 & 6.94 & 0.321 & 7.47 & 0.003 & 0.24 & 0.021 & 0.94 & 0.011 & 2.46 & $38.56 \%$ & 3545 \\
\hline Stdev & 0.006 & 1.18 & 0.045 & 1.03 & 0.016 & 0.54 & 0.017 & 0.70 & 0.006 & 1.14 & $6.72 \%$ & 1034 \\
\hline Minimum & 0.019 & 4.75 & 0.264 & 5.99 & -0.024 & -0.95 & -0.012 & -0.19 & 0.001 & 0.18 & $30.68 \%$ & 1682 \\
\hline Q1 & 0.027 & 6.20 & 0.287 & 6.71 & -0.008 & -0.11 & 0.009 & 0.46 & 0.008 & 2.06 & $33.49 \%$ & 2587 \\
\hline Median & 0.031 & 6.80 & 0.314 & 7.23 & 0.002 & 0.25 & 0.021 & 0.87 & 0.012 & 2.68 & $36.73 \%$ & 3910 \\
\hline Q3 & 0.034 & 7.58 & 0.343 & 7.87 & 0.012 & 0.58 & 0.034 & 1.38 & 0.015 & 3.24 & $40.60 \%$ & 4423 \\
\hline Maximum & 0.046 & 9.54 & 0.469 & 10.35 & 0.043 & 1.43 & 0.049 & 2.65 & 0.022 & 4.57 & $54.06 \%$ & 4859 \\
\hline \multicolumn{13}{|c|}{ Panel B: by industry, mean value for 30 -year } \\
\hline Industry & $\delta_{1}$ & t-stat & $\delta_{2}$ & t-stat & $\delta_{3}$ & t-stat & $\delta_{4}$ & t-stat & $\delta_{5}$ & t-stat & $\operatorname{adj}-R^{2}$ & $\mathrm{~N}$ \\
\hline 1 & 0.034 & 8.25 & 0.279 & 6.74 & 0.015 & 0.80 & 0.008 & 0.45 & 0.016 & 3.99 & $40.09 \%$ & 20985 \\
\hline 2 & 0.040 & 8.34 & 0.299 & 8.57 & 0.002 & 0.07 & 0.018 & 1.21 & 0.010 & 2.01 & $36.30 \%$ & 26202 \\
\hline 3 & 0.032 & 8.22 & 0.267 & 7.56 & -0.001 & -0.04 & 0.022 & 1.04 & 0.010 & 2.45 & $34.54 \%$ & 19917 \\
\hline 4 & 0.015 & 1.66 & 0.454 & 5.78 & -0.007 & -0.15 & 0.039 & 0.89 & 0.007 & 0.77 & $43.68 \%$ & 7818 \\
\hline 5 & 0.037 & 8.21 & 0.307 & 8.69 & 0.005 & 0.54 & 0.018 & 1.11 & 0.014 & 3.08 & $38.20 \%$ & 31440 \\
\hline Average & 0.032 & 6.94 & 0.321 & 7.47 & 0.003 & 0.24 & 0.021 & 0.94 & 0.011 & 2.46 & $38.56 \%$ & 21272 \\
\hline
\end{tabular}


Table 3

Implied Cost of Capital, Growth Rate, Valuation Multiples, and Risk Premium

Table 3 reports the implied cost of capital, growth rate, valuation multiples and the risk premium for each of the 150 industry-year portfolios for 5 -industry over 1980 -2009. Industry classification is per Ken French's website. Growth rate, implied cost of capital, valuation multiples and conservatism parameter are: $g=\frac{1+\delta_{2}+\delta_{3}-\delta_{5}+\sqrt{\left(1+\delta_{2}+\delta_{3}-\delta_{5}\right)^{2}-4\left(\delta_{2}-\delta_{4}-\delta_{5}\right)}}{2}-1, R-1=(1+g)\left(1+\frac{\delta_{1}+\delta_{5}}{1+g-\delta_{2}}\right)-1, \alpha_{1}=1+\frac{\delta_{4}+\delta_{5}}{(1+g)-\delta_{2}}, \alpha_{2}=\frac{\delta_{2}-\delta_{4}-\delta_{5}}{(1+g)-\delta_{2}}, \lambda=\frac{(1+g) \delta_{5}}{1+g-\delta_{2}}$ respectively, where $\delta_{\mathrm{i}}(\mathrm{i}=1-$ 5) are from regression: $\frac{f e p s_{t+1}}{P_{t}}=\delta_{1}+\delta_{2} \frac{e_{t}}{P_{t}}+\delta_{3} \frac{b_{t}}{P_{t}}+\delta_{4} \frac{b_{t-1}}{P_{t}}+\delta_{5} \frac{P_{t-1}}{P_{t}}+\varepsilon_{t+1}$, over a two-year rolling window. The risk premium (RP) is calculated relative to the yield on a 10year US government bond. feps $s_{t+1}$ is the median consensus forecasts of earnings at the first month after the corresponding I/B/E/S-reported prior-year earnings announcements; $P_{t}$ and $P_{t-1}$ are the contemporary equity price and lagged equity price respectively; $b_{t}$ and $b_{t-1}$ are the contemporary book value of equity and lagged book value of equity respectively; $e_{t}$ is net income before extraordinary items. $\mathrm{N}$ is the numbers of observations in a two-year rolling window. The descriptive statistics are also reported. Panels A and B report the results on a year-by-year basis and industry-by-industry basis respectively.

\begin{tabular}{|c|c|c|c|c|c|c|c|c|c|c|c|}
\hline \multicolumn{12}{|c|}{ Panel A: by year, mean value for 5-industry } \\
\hline Year & $\operatorname{ICC}(\%)$ & t-stat & $\mathrm{g}(\%)$ & t-stat & $\alpha_{1}$ & t-stat & $\alpha_{2}$ & t-stat & $\lambda$ & t-stat & $\mathrm{RP}(\%)$ \\
\hline $79-80$ & 14.70 & 29.45 & 2.20 & 4.19 & 1.052 & 19.48 & 0.826 & 3.87 & 0.037 & 3.62 & 3.28 \\
\hline $80-81$ & 14.40 & 30.24 & 4.40 & 5.40 & 1.053 & 22.81 & 0.610 & 4.22 & 0.026 & 3.20 & 0.48 \\
\hline $81-82$ & 13.30 & 31.12 & 4.00 & 5.37 & 1.083 & 25.82 & 0.477 & 4.16 & 0.030 & 4.47 & 0.33 \\
\hline $82-83$ & 13.00 & 32.4 & 5.30 & 6.19 & 1.021 & 27.76 & 0.592 & 4.70 & 0.029 & 4.93 & 1.86 \\
\hline $83-84$ & 12.10 & 35.04 & 4.60 & 6.11 & 0.995 & 28.29 & 0.561 & 5.41 & 0.022 & 4.46 & -0.38 \\
\hline $84-85$ & 10.80 & 29.86 & 2.90 & 4.66 & 1.072 & 33.76 & 0.444 & 5.38 & 0.022 & 3.47 & 0.16 \\
\hline $85-86$ & 9.80 & 23.5 & 3.20 & 3.95 & 1.083 & 35.47 & 0.326 & 4.89 & 0.015 & 1.79 & 2.16 \\
\hline $86-87$ & 10.30 & 24.11 & 3.90 & 4.38 & 1.075 & 33.66 & 0.307 & 4.66 & 0.020 & 2.38 & 1.89 \\
\hline $87-88$ & 11.20 & 27.8 & 4.20 & 5.06 & 1.073 & 35.01 & 0.352 & 4.69 & 0.015 & 3.22 & 2.34 \\
\hline $88-89$ & 11.30 & 29.56 & 4.50 & 5.45 & 1.040 & 40.60 & 0.342 & 4.78 & 0.026 & 2.64 & 2.85 \\
\hline $89-90$ & 11.10 & 30.72 & 4.50 & 5.03 & 1.050 & 40.60 & 0.328 & 4.40 & 0.031 & 4.09 & 2.60 \\
\hline $90-91$ & 10.50 & 29.18 & 4.30 & 5.45 & 1.058 & 36.77 & 0.339 & 4.60 & 0.023 & 4.72 & 2.66 \\
\hline $91-92$ & 9.60 & 26.49 & 4.10 & 5.40 & 1.035 & 41.21 & 0.341 & 4.50 & 0.006 & 2.12 & 2.63 \\
\hline $92-93$ & 9.40 & 24.63 & 3.30 & 4.63 & 1.073 & 39.14 & 0.494 & 4.59 & 0.018 & 3.61 & 3.49 \\
\hline $93-94$ & 10.20 & 28.99 & 4.40 & 4.89 & 1.065 & 38.11 & 0.441 & 4.75 & 0.020 & 3.11 & 3.08 \\
\hline $94-95$ & 10.30 & 27.55 & 4.90 & 5.05 & 1.027 & 43.63 & 0.358 & 4.79 & 0.018 & 3.78 & 3.76 \\
\hline $95-96$ & 9.60 & 26.36 & 4.40 & 5.21 & 1.037 & 44.02 & 0.317 & 5.21 & 0.017 & 3.26 & 3.13 \\
\hline $96-97$ & 9.20 & 25.01 & 4.70 & 5.11 & 1.062 & 46.48 & 0.287 & 4.78 & 0.014 & 3.53 & 2.85 \\
\hline $97-98$ & 8.80 & 20.44 & 3.90 & 3.66 & 1.081 & 54.28 & 0.383 & 5.76 & 0.018 & 4.80 & 3.54 \\
\hline $98-99$ & 9.40 & 24.99 & 4.10 & 5.07 & 1.096 & 51.10 & 0.476 & 6.33 & 0.024 & 3.85 & 3.71 \\
\hline
\end{tabular}




\begin{tabular}{|c|c|c|c|c|c|c|c|c|c|c|c|}
\hline 99-00 & 9.60 & 29.7 & 4.30 & 5.91 & 1.094 & 43.18 & 0.416 & 5.05 & 0.017 & 4.39 & 3.59 \\
\hline 00-01 & 8.20 & 21.86 & 3.70 & 4.94 & 1.037 & 36.32 & 0.374 & 5.42 & 0.001 & 1.56 & 3.15 \\
\hline 01-02 & 7.50 & 20.51 & 2.80 & 3.47 & 1.013 & 40.62 & 0.394 & 6.05 & 0.000 & 2.39 & 2.84 \\
\hline $02-03$ & 7.10 & 19.97 & 2.20 & 2.67 & 1.042 & 42.07 & 0.518 & 6.54 & 0.011 & 4.13 & 3.08 \\
\hline 03-04 & 5.80 & 14.8 & 1.00 & 1.49 & 1.004 & 43.00 & 0.611 & 6.14 & 0.002 & 0.74 & 1.53 \\
\hline 04-05 & 5.40 & 14.12 & 0.60 & 1.11 & 0.991 & 37.76 & 0.498 & 5.73 & 0.004 & 0.85 & 1.14 \\
\hline $05-06$ & 5.10 & 13.48 & 0.20 & 0.60 & 1.019 & 37.19 & 0.459 & 5.92 & 0.005 & 1.71 & 0.29 \\
\hline $06-07$ & 5.90 & 12.44 & 0.80 & 0.38 & 1.050 & 35.50 & 0.482 & 6.06 & 0.010 & 2.78 & 1.23 \\
\hline 07-08 & 6.60 & 15.43 & 1.40 & 1.21 & 1.045 & 45.42 & 0.417 & 6.01 & 0.012 & 2.58 & 2.93 \\
\hline 08-09 & 6.70 & 21.14 & 1.30 & 1.41 & 1.018 & 45.75 & 0.371 & 6.75 & 0.009 & 3.49 & 3.45 \\
\hline Average & 9.54 & 24.70 & 3.34 & 4.12 & 1.048 & 38.16 & 0.438 & 5.20 & 0.017 & 3.19 & 2.32 \\
\hline Stdev & 2.55 & 6.12 & 1.45 & 1.75 & 0.029 & 7.83 & 0.118 & 0.77 & 0.009 & 1.13 & 1.20 \\
\hline Minimum & 5.10 & 12.44 & 0.20 & 0.38 & 0.991 & 19.48 & 0.287 & 3.87 & 0.000 & 0.74 & -0.38 \\
\hline Q1 & 7.68 & 20.67 & 2.35 & 3.51 & 1.029 & 35.13 & 0.344 & 4.67 & 0.011 & 2.44 & 1.61 \\
\hline Median & 9.60 & 25.69 & 3.95 & 4.91 & 1.050 & 38.63 & 0.417 & 4.97 & 0.017 & 3.36 & 2.75 \\
\hline Q3 & 11.03 & 29.53 & 4.40 & 5.33 & 1.073 & 43.14 & 0.491 & 5.88 & 0.023 & 4.03 & 3.14 \\
\hline Maximum & 14.70 & 35.04 & 5.30 & 6.19 & 1.096 & 54.28 & 0.826 & 6.75 & 0.037 & 4.93 & 3.76 \\
\hline \multicolumn{12}{|c|}{ Panel B: by industry, mean value for 30 -year } \\
\hline Industry & $\mathrm{ICC}(\%)$ & t-stat & $\mathrm{g}(\%)$ & t-stat & $\alpha_{1}$ & t-stat & $\alpha_{2}$ & t-stat & $\lambda$ & t-stat & $\mathrm{RP}(\%)$ \\
\hline 1 & 10.00 & 28.22 & 3.00 & 5.08 & 1.034 & 40.38 & 0.352 & 5.10 & 0.023 & 4.89 & 2.79 \\
\hline 2 & 9.80 & 32.42 & 2.80 & 4.17 & 1.04 & 45.21 & 0.383 & 5.98 & 0.014 & 2.70 & 2.59 \\
\hline 3 & 8.40 & 18.77 & 2.70 & 3.28 & 1.043 & 40.13 & 0.314 & 5.74 & 0.014 & 3.07 & 1.21 \\
\hline 4 & 8.90 & 5.93 & 5.00 & 2.33 & 1.077 & 12.69 & 0.745 & 3.30 & 0.013 & 0.90 & 1.67 \\
\hline 5 & 10.60 & 38.15 & 3.20 & 5.72 & 1.048 & 52.38 & 0.396 & 5.91 & 0.020 & 4.38 & 3.36 \\
\hline Average & 9.54 & 24.70 & 3.34 & 4.12 & 1.048 & 38.16 & 0.438 & 5.20 & 0.017 & 3.19 & 2.32 \\
\hline
\end{tabular}




\section{Table 4}

\section{Excess Realized Return, Implied Risk Premium and Risk Proxies}

Panel A of this table reports descriptive statistics of excess realized return, estimated risk premium and risk proxies over 1980-2009. Annual realized returns are calculated by compounding 12monthly returns from April of year $t$ to March of year $t+1$. XRET1 is excess one-year ahead realized returns over the yields of 10-year US government bond. ERP is expected risk premium, which is equal to the difference between the implied cost of capital (ICC) and 10-year US government bond yields. CFN equals actual earnings per share for year $t+1$ less analysts' forecasts of one-year-ahead earnings per share, scaled by stock price at time t. DRN is measured by the one-year-ahead change in the yields of the five-year treasury constant maturity as of the month the expected return estimates. Term (spread) is calculated as the difference between 10-Year US Treasury constant maturity rate and the 3-Month US T-Bill yields. Default (spread) is calculated as the difference between Moody's Seasoned Baa and Aaa Corporate Bond yields. Data on corporate bonds and US T-Bills/Bonds are obtained from the FRED database of the Federal Reserve Bank of St. Louis. Size is the logarithm of a firm's market capitalization. Lev is total debt dividend by the firm's market capitalization as of 3-month after the fiscal year end. Beta is estimated via the market model using the value weighted NYSE/Amex market index return using at least 18 and up to 60 months of lagged monthly returns. Panel B shows the Pearson correlations for 38,651 firm-year observations. Panel C reports one-year ahead realized returns for ICC quintile sorted portfolio, as well as the average return spread between quintiles 5 and 1.

\begin{tabular}{|c|c|c|c|c|c|c|c|c|c|}
\hline \multicolumn{10}{|c|}{ Panel A: Descriptive Statistics } \\
\hline $\mathrm{N}$ & 38651 & 45021 & 44697 & 45021 & 43845 & 45021 & 44701 & 45021 & 45021 \\
\hline Mean & 0.110 & 0.047 & -0.044 & -0.248 & 1.058 & 6.014 & 0.699 & 1.685 & 1.095 \\
\hline Stdev & 0.535 & 0.047 & 0.156 & 1.003 & 0.610 & 1.723 & 1.922 & 1.373 & 0.582 \\
\hline $5 \%$ & -0.542 & 0.005 & -0.224 & -1.630 & 0.213 & 3.360 & 0.000 & -0.530 & 0.640 \\
\hline Q1 & -0.198 & 0.019 & -0.029 & -1.000 & 0.614 & 4.753 & 0.060 & 0.580 & 0.690 \\
\hline Median & 0.041 & 0.035 & -0.003 & -0.270 & 0.984 & 5.924 & 0.260 & 1.580 & 0.960 \\
\hline Q3 & 0.309 & 0.058 & 0.004 & 0.460 & 1.395 & 7.182 & 0.714 & 2.840 & 1.180 \\
\hline $95 \%$ & 0.967 & 0.135 & 0.025 & 1.550 & 2.202 & 9.061 & 2.547 & 3.540 & 2.320 \\
\hline \multicolumn{10}{|c|}{ Panel B: Correlation } \\
\hline XRET1 & $\begin{array}{c}\text { XRET1 } \\
1\end{array}$ & ERP & CFN & DRN & Beta & Size & Lev & Term & Default \\
\hline ERP & 0.143 & 1 & & & & & & & \\
\hline $\mathrm{CFN}$ & 0.181 & -0.280 & 1 & & & & & & \\
\hline DRN & -0.049 & 0.006 & 0.067 & 1 & & & & & \\
\hline Beta & 0.007 & 0.059 & -0.086 & -0.011 & 1 & & & & \\
\hline Size & -0.056 & -0.244 & 0.236 & 0.005 & -0.054 & 1 & & & \\
\hline Lev & 0.060 & 0.226 & -0.158 & -0.023 & -0.030 & -0.074 & 1 & & \\
\hline Term & 0.135 & 0.013 & 0.045 & -0.155 & -0.005 & 0.016 & 0.003 & 1 & \\
\hline Default & 0.165 & 0.143 & -0.032 & -0.143 & 0.045 & -0.025 & 0.083 & 0.165 & 1 \\
\hline \multicolumn{10}{|c|}{ Panel C: Returns on ICC-sorted portfolios } \\
\hline \multicolumn{3}{|c|}{ ICC quintiles } & 1 & 2 & \multicolumn{2}{|c|}{3} & 4 & 5 & \multirow{2}{*}{$\begin{array}{c}\text { Q5-Q1 } \\
0.107\end{array}$} \\
\hline \multicolumn{3}{|c|}{ Mean of ICC } & 0.073 & 0.087 & \multicolumn{2}{|c|}{0.099} & 0.116 & 0.179 & \\
\hline \multicolumn{3}{|c|}{ Mean of one-year ahead realized returns } & 0.090 & 0.091 & & & 0.111 & 0.172 & 0.082 \\
\hline
\end{tabular}


Table 5

\section{Regressing Excess One-year-ahead Realized Returns on the Implied Risk Premium and Risk Proxies}

Panel A of this table presents regression coefficients (t-values) of excess one-year-ahead realized returns (XRET1) on expected risk premium (ERP) and risk proxies. Two-way cluster-robust standard errors are used to correct for both cross-sectional and time-series dependence. Risk-free rate is proxied by 10 -year US government bond yields. CFN equals actual earnings per share for year $t+1$ less analysts' forecasts of one-year-ahead earnings per share, scaled by stock price at time t. DRN is measured by the one-year-ahead change in the yields of the five-year treasury constant maturity as of the month the expected return estimates. Term (spread) is calculated as the difference between 10-Year US Treasury constant maturity rate and the 3-Month US T-Bill yields. Default (spread) is calculated as the difference between Moody's Seasoned Baa and Aaa Corporate Bond yields. Size is the logarithm of a firm's market capitalization. Lev is total debt divided by the firm's market capitalization as of 3-month after the fiscal year end. Beta is estimated via the market model using the value weighted NYSE/Amex market index return using at least 18 and up to 60 months of lagged monthly returns. B/P is ratio of book-to-price. Panel B reports regression coefficients of the difference between XRET1 and ERP, DRET1, on expected risk premium and risk proxies.

\begin{tabular}{|c|c|c|c|c|c|c|c|c|c|}
\hline Panel A. & XRET1 & XRET1 & XRET1 & XRET1 & XRET1 & XRET1 & $\begin{array}{l}\text { Panel B. } \\
\text { DRET1 }\end{array}$ & DRET1 & DRET1 \\
\hline \multirow[t]{2}{*}{ ERP } & 1.800 & 2.440 & 2.210 & 1.940 & 1.550 & 1.770 & 0.803 & 1.440 & 1.170 \\
\hline & (3.02) & $(4.47)$ & $(3.96)$ & $(4.01)$ & (3.98) & $(5.35)$ & $(1.35)$ & $(2.64)$ & $(3.20)$ \\
\hline \multirow[t]{2}{*}{$\mathrm{CFN}$} & & 1.300 & 1.390 & 1.440 & & 1.410 & & 1.300 & 1.290 \\
\hline & & (15.87) & (16.15) & (16.49) & & (15.47) & & (15.87) & (16.09) \\
\hline \multirow[t]{2}{*}{ DRN } & & -0.034 & -0.035 & -0.033 & & -0.015 & & -0.034 & -0.015 \\
\hline & & $(-0.89)$ & $(-0.89)$ & $(-0.85)$ & & $(-0.37)$ & & $(-0.89)$ & $(-0.37)$ \\
\hline \multirow[t]{2}{*}{ Beta } & & & 0.016 & 0.019 & & 0.014 & & & \\
\hline & & & $(0.48)$ & $(0.58)$ & & $(0.45)$ & & & \\
\hline \multirow[t]{2}{*}{ Size } & & & -0.023 & -0.015 & & -0.017 & & & \\
\hline & & & $(-2.45)$ & $(-1.55)$ & & $(-2.05)$ & & & \\
\hline \multirow[t]{2}{*}{ Lev } & & & 0.014 & 0.002 & & & & & \\
\hline & & & $(3.36)$ & $(0.44)$ & & & & & \\
\hline \multirow[t]{2}{*}{$\mathrm{B} / \mathrm{P}$} & & & & 0.108 & & 0.084 & & & \\
\hline & & & & (3.11) & & (4.67) & & & \\
\hline \multirow[t]{2}{*}{ Term } & & & & & 0.044 & 0.039 & & & 0.038 \\
\hline & & & & & (1.51) & (1.37) & & & (1.36) \\
\hline \multirow[t]{2}{*}{ Default } & & & & & 0.121 & 0.113 & & & 0.124 \\
\hline & & & & & (1.77) & (1.66) & & & (1.94) \\
\hline \multirow[t]{2}{*}{ constant } & 0.030 & 0.027 & 0.155 & 0.060 & -0.167 & -0.089 & 0.030 & 0.027 & -0.159 \\
\hline & $(0.75)$ & $(0.74)$ & $(1.96)$ & (0.61) & $(-1.69)$ & $(-0.70)$ & $(0.75)$ & $(0.74)$ & $(-1.68)$ \\
\hline $\operatorname{adj}-R^{2}$ & $2.04 \%$ & $7.15 \%$ & $7.77 \%$ & $8.63 \%$ & $5.43 \%$ & $11.30 \%$ & $0.41 \%$ & $5.61 \%$ & $8.68 \%$ \\
\hline
\end{tabular}


Table 6

\section{Relation Between Implied Risk Premium and Risk Proxies}

This table presents regression coefficients (t-values) of expected risk premium (ERP) on various risk proxies. Two-way cluster-robust standard errors are used to correct for both cross-sectional and time-series dependence. Risk-free rate is proxied by 10-year US government bond yields. Term (spread) is calculated as the difference between 10Year US Treasury constant maturity rate and the 3-Month US T-Bill yields. Default (spread) is calculated as the difference between Moody's Seasoned Baa and Aaa

Corporate Bond yields. Size is the logarithm of a firm's market capitalization. Lev is total debt dividend by the firm's market capitalization as of 3-months after the fiscal year end. Beta is estimated via the market model using the value weighted NYSE/Amex market index return using at least 18 and up to 60 months of lagged monthly returns. $\mathrm{B} / \mathrm{P}$ is the book-to-price ratio. E/P is the ratio of current earnings to price. FE/P is the ratio of one-year-ahead analysts' forecasts of earnings to price. Stdev is the standard deviation of annual stock returns.

\begin{tabular}{|c|c|c|c|c|c|c|c|c|c|c|c|}
\hline Beta & $\begin{array}{l}0.005 \\
(2.67)\end{array}$ & & & & $\begin{array}{l}0.004 \\
(2.74)\end{array}$ & $\begin{array}{l}0.004 \\
(2.64)\end{array}$ & $\begin{array}{l}0.004 \\
(2.44)\end{array}$ & $\begin{array}{l}0.004 \\
(2.92)\end{array}$ & & & $\begin{array}{l}-0.003 \\
(-1.41)\end{array}$ \\
\hline Size & & $\begin{array}{c}-0.007 \\
(-12.39)\end{array}$ & & & $\begin{array}{c}-0.004 \\
(-10.12)\end{array}$ & & $\begin{array}{c}-0.006 \\
(-11.37)\end{array}$ & $\begin{array}{c}-0.005 \\
(-10.99)\end{array}$ & & & $\begin{array}{l}-0.005 \\
(-9.46)\end{array}$ \\
\hline Lev & & & $\begin{array}{l}0.006 \\
(7.48)\end{array}$ & & & & $\begin{array}{l}0.005 \\
(7.51)\end{array}$ & $\begin{array}{l}0.003 \\
(5.71)\end{array}$ & & & $\begin{array}{l}0.005 \\
(7.57)\end{array}$ \\
\hline $\mathrm{B} / \mathrm{P}$ & & & & $\begin{array}{l}0.026 \\
(7.47)\end{array}$ & $\begin{array}{l}0.023 \\
(6.75)\end{array}$ & & & $\begin{array}{l}0.018 \\
(6.13)\end{array}$ & & $\begin{array}{l}-0.003 \\
(-1.09)\end{array}$ & \\
\hline Term & & & & & & $\begin{array}{l}0.000 \\
(-0.3)\end{array}$ & $\begin{array}{c}0.000 \\
(-0.13)\end{array}$ & $\begin{array}{c}0.000 \\
(-0.17)\end{array}$ & & & \\
\hline Default & & & & & & $\begin{array}{l}0.012 \\
(5.37)\end{array}$ & $\begin{array}{l}0.010 \\
(3.05)\end{array}$ & $\begin{array}{l}0.007 \\
(2.06)\end{array}$ & & & \\
\hline $\mathrm{E} / \mathrm{P}$ & & & & & & & & & $\begin{array}{c}-0.171 \\
(-12.95)\end{array}$ & $\begin{array}{c}-0.173 \\
(-12.23)\end{array}$ & \\
\hline $\mathrm{FE} / \mathrm{P}$ & & & & & & & & & $\begin{array}{l}0.588 \\
(23.5)\end{array}$ & $\begin{array}{c}0.601 \\
(18.94)\end{array}$ & \\
\hline Stdev & & & & & & & & & & & $\begin{array}{l}0.046 \\
(6.24)\end{array}$ \\
\hline constant & $\begin{array}{c}0.043 \\
(19.59)\end{array}$ & $\begin{array}{c}0.088 \\
(19.08)\end{array}$ & $\begin{array}{c}0.043 \\
(21.73)\end{array}$ & $\begin{array}{c}0.030 \\
(11.77)\end{array}$ & $\begin{array}{c}0.054 \\
(10.41)\end{array}$ & $\begin{array}{l}0.031 \\
(5.67)\end{array}$ & $\begin{array}{l}0.067 \\
(9.77)\end{array}$ & $\begin{array}{l}0.050 \\
(7.69)\end{array}$ & $\begin{array}{l}0.004 \\
(1.72)\end{array}$ & $\begin{array}{l}0.005 \\
(2.17)\end{array}$ & $\begin{array}{c}0.057 \\
(11.45)\end{array}$ \\
\hline $\operatorname{adj}-R^{2}$ & $0.34 \%$ & $5.94 \%$ & $5.12 \%$ & $11.30 \%$ & $14.10 \%$ & $2.35 \%$ & $11.90 \%$ & $15.90 \%$ & $58.60 \%$ & $58.70 \%$ & $12.10 \%$ \\
\hline
\end{tabular}


Table 7

\section{Excess Realized Return, Implied Risk Premium and Risk Proxies Using Adjusted Forecasts of Earnings}

Panel A of this table reports descriptive statistics of excess realized return, estimated risk premium and risk proxies by using adjusted forecasts of earnings over 1980-2009. Annual realized returns are calculated by compounding 12-monthly returns from April of year $\mathrm{t}$ to March of year $\mathrm{t}+1$. XRET1 is excess one-year ahead realized returns over the yields of 10 -year US government bond. ERP is expected risk premium = implied cost of capital (ICC) - 10-year US government bond yields. CFN equals actual earnings per share for year t+1 less analysts' forecasts of one-yearahead earnings per share, scaled by stock price at time t. DRN is measured by the one-year-ahead change in the yields of the five-year treasury constant maturity as of the month the expected return estimates. Term (spread) is calculated as the difference between 10-Year US Treasury constant maturity rate and the 3-Month US T-Bill yields. Default (spread) is calculated as the difference between Moody's Seasoned Baa and Aaa Corporate Bond yields. Data on corporate bonds and US T-Bills/Bonds are obtained from the FRED database of the Federal Reserve Bank of St. Louis. Size is the logarithm of a firm's market capitalization. Lev is total debt dividend by the firm's market capitalization as of 3-months after the fiscal year end. Beta is estimated via the market model using the value weighted NYSE/Amex market index return using at least 18 and up to 60 months of lagged monthly returns. Panel B shows the Pearson correlations for 35,379 firm-year observations. Panel C reports one-year ahead realized returns for ICC quintile sorted portfolio, as well as the average return spread between quintiles 5 and 1.

\section{Panel A: Descriptive Statistics}

\begin{tabular}{|c|c|c|c|c|c|c|c|c|c|}
\hline & XRET1 & ERP & $\mathrm{CFN}$ & DRN & Beta & Size & Lev & Term & Default \\
\hline $\mathrm{N}$ & 35379 & 41707 & 40618 & 41707 & 40601 & 41707 & 41407 & 41707 & 41707 \\
\hline Mean & 0.131 & 0.064 & -0.026 & -0.257 & 1.059 & 5.895 & 0.785 & 1.700 & 1.124 \\
\hline Stdev & 0.560 & 0.079 & 0.132 & 0.989 & 0.613 & 1.748 & 2.193 & 1.367 & 0.614 \\
\hline $5 \%$ & -0.533 & 0.004 & -0.200 & -1.630 & 0.209 & 3.235 & 0.000 & -0.530 & 0.640 \\
\hline Q1 & -0.189 & 0.020 & -0.015 & -1.000 & 0.610 & 4.608 & 0.074 & 0.580 & 0.690 \\
\hline Median & 0.052 & 0.039 & 0.005 & -0.270 & 0.984 & 5.782 & 0.300 & 1.580 & 0.980 \\
\hline Q3 & 0.327 & 0.074 & 0.017 & 0.460 & 1.400 & 7.086 & 0.796 & 2.840 & 1.240 \\
\hline $95 \%$ & 1.039 & 0.213 & 0.051 & 1.550 & 2.204 & 9.014 & 2.814 & 3.540 & 2.320 \\
\hline \multicolumn{10}{|c|}{ Panel B: Correlation } \\
\hline & XRET1 & ERP & $\mathrm{CFN}$ & DRN & Beta & Size & Lev & Term & Default \\
\hline XRET1 & 1 & & & & & & & & \\
\hline ERP & 0.160 & 1 & & & & & & & \\
\hline CFN & 0.174 & -0.268 & 1 & & & & & & \\
\hline DRN & -0.053 & -0.051 & 0.076 & 1 & & & & & \\
\hline Beta & 0.032 & 0.136 & -0.073 & -0.046 & 1 & & & & \\
\hline Size & -0.061 & -0.314 & 0.210 & 0.018 & -0.070 & 1 & & & \\
\hline Lev & 0.059 & 0.219 & -0.117 & -0.019 & -0.023 & -0.073 & 1 & & \\
\hline Term & 0.131 & 0.032 & 0.070 & -0.151 & 0.009 & 0.019 & 0.000 & 1 & \\
\hline Default & 0.185 & 0.170 & -0.021 & -0.164 & 0.065 & -0.017 & 0.079 & 0.183 & 1 \\
\hline \multicolumn{10}{|c|}{ Panel C: Returns on ICC-sorted portfolios } \\
\hline \multicolumn{3}{|c|}{ ICC quintiles } & 1 & 2 & \multicolumn{2}{|c|}{3} & 4 & 5 & Q5-Q1 \\
\hline \multicolumn{3}{|c|}{ Mean of ICC } & 0.072 & 0.088 & \multicolumn{2}{|c|}{0.105} & 0.131 & 0.261 & 0.188 \\
\hline \multicolumn{3}{|c|}{ Mean of one-year ahead realized returns } & 0.102 & 0.111 & \multicolumn{2}{|c|}{0.116} & 0.133 & 0.204 & 0.102 \\
\hline
\end{tabular}


Table 8

\section{Regressing Excess One-year-ahead Realized Returns on the Implied Risk Premium and Risk Proxies Using Adjusted Forecasts of Earnings}

Panel A of this table presents regression coefficients (t-values) of excess one-year-ahead realized returns (XRET1) on expected risk premium (ERP) and risk proxies by using adjusted forecasts of earnings. Two-way cluster-robust standard errors are used to correct for both cross-sectional and time-series dependence. Risk-free rate is proxied by 10 -year US government bond yields. CFN equals actual earnings per share for year $\mathrm{t}+1$ less analysts' forecasts of one-year-ahead earnings per share, scaled by stock price at time $t$. DRN is measured by the one-year-ahead change in the yields of the five-year treasury constant maturity as of the month the expected return estimates. Term (spread) is calculated as the difference between 10-Year US Treasury constant maturity rate and the 3-Month US T-Bill yields. Default (spread) is calculated as the difference between Moody's Seasoned Baa and Aaa Corporate Bond yields. Size is the logarithm of a firm's market capitalization. Lev is total debt dividend by the firm's market capitalization as of 3-months after the fiscal year end. Beta is estimated via the market model using the value weighted NYSE/Amex market index return using at least 18 and up to 60 months of lagged monthly returns. B/P is the book-to-price ratio. Panel B reports regression coefficients of difference between XRET1 and ERP, DRET1, on expected risk premium and risk proxies.

Panel A.

\begin{tabular}{|c|c|c|c|c|c|c|c|c|c|}
\hline 20 & XRET1 & XRET1 & XRET1 & XRET1 & XRET1 & XRET1 & DRET1 & DRET1 & DRET1 \\
\hline \multirow[t]{2}{*}{ ERP } & 1.310 & 1.730 & 1.580 & 1.450 & 1.070 & 1.260 & 0.309 & 0.731 & 0.497 \\
\hline & $(2.9)$ & (4.01) & $(3.52)$ & $(3.49)$ & $(3.48)$ & (4.69) & (0.68) & (1.69) & (1.69) \\
\hline \multirow[t]{2}{*}{ CFN } & & 1.43 & 1.48 & 1.48 & & 1.43 & & 1.43 & 1.39 \\
\hline & & (12.04) & (12.38) & (12.77) & & (13.4) & & (12.04) & (13.27) \\
\hline \multirow[t]{2}{*}{ DRN } & & -0.032 & -0.032 & -0.031 & & -0.011 & & -0.032 & -0.011 \\
\hline & & $(-0.75)$ & $(-0.76)$ & $(-0.74)$ & & $(-0.24)$ & & $(-0.75)$ & $(-0.25)$ \\
\hline \multirow[t]{2}{*}{ Beta } & & & 0.018 & 0.019 & & 0.013 & & & \\
\hline & & & $(0.5)$ & $(0.53)$ & & (0.39) & & & \\
\hline \multirow[t]{2}{*}{ Size } & & & -0.015 & -0.011 & & -0.014 & & & \\
\hline & & & $(-1.41)$ & $(-0.97)$ & & $(-1.51)$ & & & \\
\hline \multirow[t]{2}{*}{ Lev } & & & 0.009 & 0.002 & & & & & \\
\hline & & & $(2.54)$ & $(0.4)$ & & & & & \\
\hline \multirow[t]{2}{*}{$\mathrm{B} / \mathrm{P}$} & & & & 0.060 & & 0.043 & & & \\
\hline & & & & (2.67) & & (3.94) & & & \\
\hline \multirow[t]{2}{*}{ Term } & & & & & 0.041 & 0.033 & & & 0.033 \\
\hline & & & & & (1.32) & (1.1) & & & (1.09) \\
\hline \multirow[t]{2}{*}{ Default } & & & & & 0.133 & 0.128 & & & 0.132 \\
\hline & & & & & (2.08) & $(2.0)$ & & & $(2.15)$ \\
\hline \multirow[t]{2}{*}{ constant } & 0.055 & 0.041 & 0.117 & 0.062 & -0.152 & -0.091 & 0.055 & 0.041 & -0.147 \\
\hline & $(1.29)$ & (1.07) & $(1.36)$ & $(0.64)$ & $(-1.54)$ & $(-0.72)$ & (1.29) & (1.07) & $(-1.51)$ \\
\hline $\operatorname{adj}-R^{2}$ & $2.54 \%$ & $7.34 \%$ & $7.63 \%$ & $8.00 \%$ & $6.08 \%$ & $10.80 \%$ & $0.14 \%$ & $5.00 \%$ & $7.98 \%$ \\
\hline
\end{tabular}


Table 9

\section{Relation Between Implied Risk Premium and Risk Proxies Using Adjusted Forecasts of Earnings}

This table presents regression coefficients (t-values) of expected risk premium (ERP) on various risk proxies by using adjusted forecasts of earnings. Two-way cluster-robust standard errors are used to correct for both cross-sectional and time-series dependence. Risk-free rate is proxied by 10-year US government bond yields. Term (spread) is calculated as the difference between 10-Year US Treasury constant maturity rate and the 3-Month US T-Bill yields. Default (spread) is calculated as the difference between Moody's Seasoned Baa and Aaa Corporate Bond yields. Size is the logarithm of a firm's market capitalization. Lev is total debt dividend by the firm's market capitalization as of 3-months after the fiscal year end. Beta is estimated via the market model using the value weighted NYSE/Amex market index return using at least 18 and up to 60 months of lagged monthly returns. B/P is the book-to-price ratio. E/P is the ratio of current earnings to price. FE/P is the ratio of one-year-ahead analysts' forecasts of earnings to price. Stdev is the standard deviation of annual stock returns.

\begin{tabular}{|c|c|c|c|c|c|c|c|c|c|c|c|}
\hline Beta & $\begin{array}{l}0.018 \\
(5.38)\end{array}$ & & & & $\begin{array}{l}0.015 \\
(5.79)\end{array}$ & $\begin{array}{l}0.016 \\
(5.62)\end{array}$ & $\begin{array}{l}0.014 \\
(5.81)\end{array}$ & $\begin{array}{l}0.014 \\
(6.35)\end{array}$ & & & $\begin{array}{l}0.004 \\
(1.02)\end{array}$ \\
\hline Size & & $\begin{array}{c}-0.014 \\
(-17.33)\end{array}$ & & & $\begin{array}{c}-0.011 \\
(-16.43)\end{array}$ & & $\begin{array}{c}-0.013 \\
(-15.68)\end{array}$ & $\begin{array}{c}-0.011 \\
(-17.63)\end{array}$ & & & $\begin{array}{c}-0.011 \\
(-14.22)\end{array}$ \\
\hline Lev & & & $\begin{array}{l}0.008 \\
(6.27)\end{array}$ & & & & $\begin{array}{l}0.007 \\
(6.57)\end{array}$ & $\begin{array}{l}0.004 \\
(5.53)\end{array}$ & & & $\begin{array}{l}0.008 \\
(6.34)\end{array}$ \\
\hline $\mathrm{B} / \mathrm{P}$ & & & & $\begin{array}{c}0.035 \\
(5.5)\end{array}$ & $\begin{array}{l}0.028 \\
(5.23)\end{array}$ & & & $\begin{array}{l}0.022 \\
(4.46)\end{array}$ & & $\begin{array}{l}0.010 \\
(6.05)\end{array}$ & \\
\hline Term & & & & & & $\begin{array}{l}0.000 \\
(0.11)\end{array}$ & $\begin{array}{l}0.001 \\
(0.39)\end{array}$ & $\begin{array}{l}0.001 \\
(0.34)\end{array}$ & & & \\
\hline Default & & & & & & $\begin{array}{l}0.021 \\
(9.35)\end{array}$ & $\begin{array}{l}0.018 \\
(6.39)\end{array}$ & $\begin{array}{l}0.014 \\
(4.53)\end{array}$ & & & \\
\hline $\mathrm{E} / \mathrm{P}$ & & & & & & & & & $\begin{array}{c}-0.321 \\
(-11.51)\end{array}$ & $\begin{array}{c}-0.31 \\
(-10.63)\end{array}$ & \\
\hline $\mathrm{FE} / \mathrm{P}$ & & & & & & & & & $\begin{array}{c}0.863 \\
(19.84)\end{array}$ & $\begin{array}{c}0.821 \\
(17.48)\end{array}$ & \\
\hline Stdev & & & & & & & & & & & $\begin{array}{l}0.074 \\
(4.95)\end{array}$ \\
\hline constant & $\begin{array}{c}0.046 \\
(16.29)\end{array}$ & $\begin{array}{c}0.147 \\
(20.61)\end{array}$ & $\begin{array}{c}0.058 \\
(15.96)\end{array}$ & $\begin{array}{c}0.038 \\
(7.57)\end{array}$ & $\begin{array}{c}0.091 \\
(12.11)\end{array}$ & $\begin{array}{l}0.023 \\
(3.39)\end{array}$ & $\begin{array}{c}0.100 \\
(11.37)\end{array}$ & $\begin{array}{c}0.078 \\
(10.39)\end{array}$ & $\begin{array}{c}0.000 \\
(-0.04)\end{array}$ & $\begin{array}{c}-0.004 \\
(-1.1)\end{array}$ & $\begin{array}{c}0.089 \\
(12.82)\end{array}$ \\
\hline $\operatorname{adj}-R^{2}$ & $1.86 \%$ & $9.86 \%$ & $4.80 \%$ & $11.70 \%$ & $18.50 \%$ & $4.48 \%$ & $17.30 \%$ & $20.80 \%$ & $62.10 \%$ & $62.90 \%$ & $16.60 \%$ \\
\hline
\end{tabular}

